دراسة تطبيقية للقاعدة الترجيحية " الحديث الصحيح هرجح بين الأقوال عند الاختلاف "

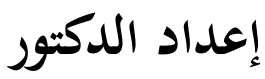 \\ فايز قاعد عايد الرويلي
}

جامعة الملك خالد - المملكة العربية السعودية

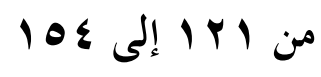


IrY 
دراسة تطبيقية للقاعدة الترجيحية

" الحديث الصحيح مرجح بين الأقوال عند الاختلاف "

فايز قاعد عايد الرويلي

جامعة الملك خالد - المملكة العربية السعودية البريا الإكتروني: جaez1428@hotmail.com

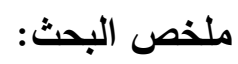

قواعد الترجيح من الأهمية بمكان لكل من يتعامل مع أقوال المفسرين لكتاب الله

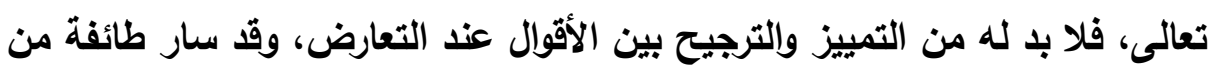
المفسرين على هذا النهج وإن لم يصرح البعض منهم بالقاعدة، ما جعل الميدان

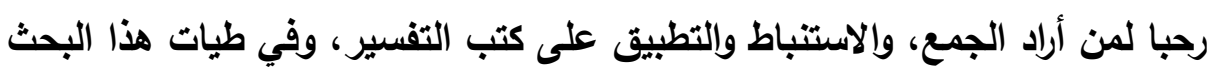

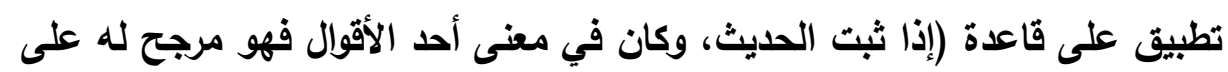

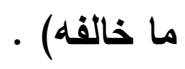

والههف من البحث : الوقوف على صورة قاعدة (الحديث الصحيح مرجح....) إلخ.

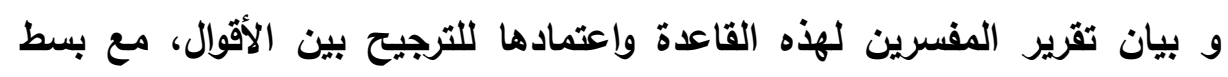
الأمثلة التطبيقية للقاعدة.

وقث سلك البحث المنهج الاستقرائي والوصفي التحليلي، من خلال تتبع أقوال

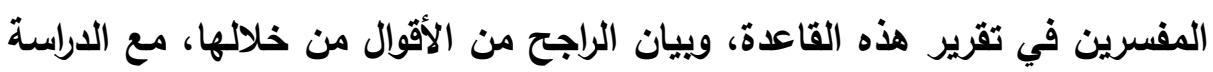

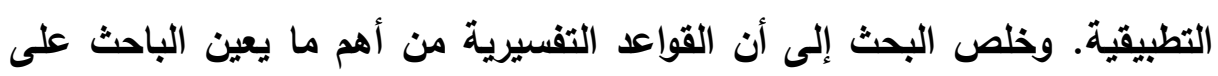

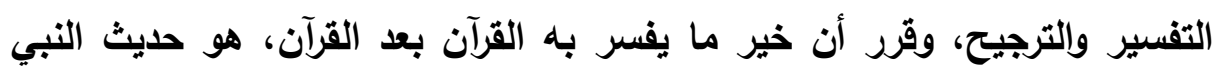

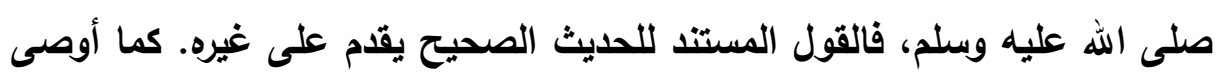
بدراسة قواعد الترجيح في سائر أمهات كتب التفسير: ابن كثير، والثوكاني، والألوسي، وابن عاشور، وغيرها، يفرد كل واحد منها برساية علمية، أو كل قاعدة فئرة على حدة ببحث.

كلمات مفتاحية: قاعدة ، ترجيح ، تفسير ، السنة . . 
A Practical Study Of The Weighting Rule

" The Right Talk Is Weighted Between Words When They Disagree. " Fayez Qaed Ayed Al-Ruwaili

King Khalid University - Saudi Arabia

Email: faez1428@hotmail.com

\section{: Research Summary}

The rules of preference are of utmost importance for everyone who deals with the sayings of the interpreters of the Qur'an, he must distinguish and choose between statements when opposing, and a group of interpreters followed this approach even if some of them did not declare the rule, which made the field wide for those who wanted to collect, devise and apply to The books of interpretation, and in the folds of this research, are applied on the basis of (if the hadith is proven, and it is in the meaning of one of the sayings, then it is likely to be based on what he violated).

The aim of the research: to stand on the base image (the correct hadith, determining the correct opinion, etc.) etc. And explain the report of the interpreters of this rule and its adoption to differentiate between words, along with simplifying the practical examples of the rule.

The research has followed the inductive and descriptive analytical method, by tracing the interpreters, with the applied study. The research concluded that the interpretative rules are among the most important things that help the researcher to interpretation and tarjeeh, and he decided that the best thing to be interpreted by the Qur'an after the Qur'an is the hadith of the Prophet, peace and blessings be upon him, and that this rule becomes true if the hadith is correct and supportive of one of the sayings. He also recommended studying the rules of preference in Tafseer: Ibn Katheer, Al-Shawkani, Al-Alusi, Ibn Ashour, and others, each one of them singling out a scientific message, or each rule separately by research.

Keywords: Base, weighting, interpretation, alsana. 


\section{بسم الله الرحمن الرحيم}

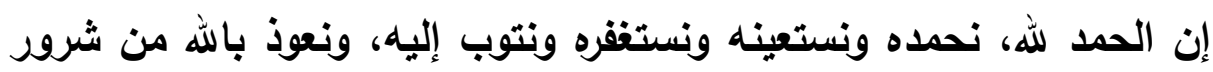

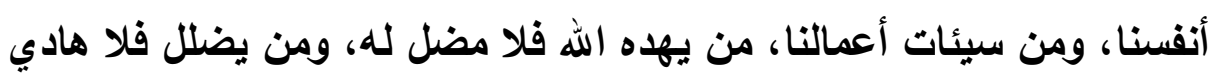

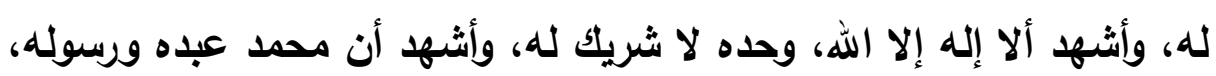
وأمينه على وحيه، وصفيه من خلقه، صلى الله عليه وعلى أله وصحبه وسلم تسليماً كثيراً.

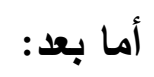

فهذا بحث يتناول قاعدة من قواعد الترجيح - التي ذكرها الدكتور حسين الحربي حفظه الله في كتابه (قواعد الترجيح عند المفسرين)' - بالاراسة، وإلنق، ويسط الأمثلة عليها - مع البعد عن الأمثلة التطبيقية اللتي ذكرها الدكتور - ما أمكن الوسع، وجادت الطاقة، فإن قواعد الترجيح من الأهمية الامبه بمكان لكل من يتعامل مع أقوال المفسرين لكتاب الله تعالى، فلا بد له من اله اله التمييز والترجيح بين الأقوال عند التعارض، فقد سار طائفة من المفسرين على هذا النهج وإن لم يصرح البعض منهم بالقاعدة، ما جعل الميدان رحبا لمن أراد الجمع، والاستنباط والتطبيق على كتب التفسير، وفي طيات هذا البحث تطبيق على قاعدة (إذا ثبت الحديث، وكان في معنى أحد الأقوال فهو

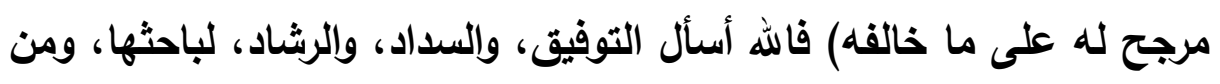
أطلع عليها.

أهداف البحث: يروم هذا البحث تحقيق الأهداف التالية. 1- التعريف بقواعد الترجيح في اللغة والاصطلاح. r- الوقوف على صورة قاعدة (الحديث الصحيح مرجح....). r- بيان تقرير المفسرين لهذه القاعدة واعتمادها للترجيح بين الأقوال. ا ينظر : قواعد الترجيح عند المفسرين للاكتور حسين الحربي († · ). 
ع - بسط الأمثلة التطبيقية للقاعدة.

منهج البحث:

سوف يسير الباحث وفق المنهج الاستقرائي والوصفي التحليلي، من خلال تتبع أقوال المفسرين في تقريز هذه القاعدة، وييان الراجح من الأقوال من من

خلالها.

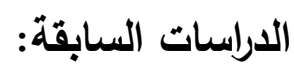

قواعد الترجيح "موضوع أغلب ظني أنه لم يلق عناية ببحث ودراسة فهو

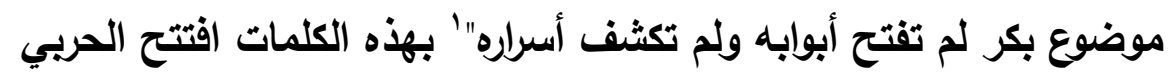
مقدمته لكتابه قواعد الترجيح وهو كما قال إلا نزر يسير لبعض الأبحاث منها بحث بعنوان القول المبين في قواعد الترجيح بين المفسرين لفهد بن عبد الله الحزمي، وقواعد الترجيح المتعلقة بالنص عند ابن عاشور في تفسيره التحرير والتتوير - دراسة تأصيلية تطبيقية - للاكتورة عبير بنت عبد الله النعيم رسالة دكتوراه جامعة الملك سعود، وأفضل ما كتب في ذلك بحسب اطلاعي كتاب قواعد الترجيح عند المفسرين دراسة نظرية تطبيقية لحسين بن علي بن حسين الحربي رسالة ماجستير فقد بسط الموضوع وأجاد فيه، وإن كان اقتصاره على تفسير الطبري، وابن عطية، وأضواء البيان للشنقيطي، إلا أنه

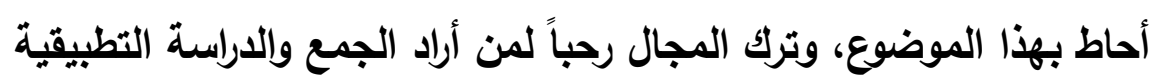
لغيرها من كتب التفسير، وما نحن بصدده في هذا البحث قاعدة من القواعد اللتي ذكرها الاكتور حسين. 
خطة البحث:

وهي عبارة عن مقدمة ومبحثين وخاتمة. المقدمة: وتشمل أهمية البحث وأهدافه، ومنهجه، وخطته، والدراسات السابقة. المبحث الأول: بين يدي القاعدة: المطلب الأول: تعريف قواعد الترجيح. لبن لدئ المطلب الثاني: صورة القاعدة. المبحث الثاني: التطبيقات على القاعدة: المطلب الأول: أقوال العلماء في تقرير القاعدة. المطلب الثاني: الأمثثة التطبيقية على القاعدة. الخاتمة. الفهارس. 


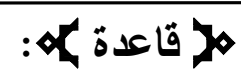

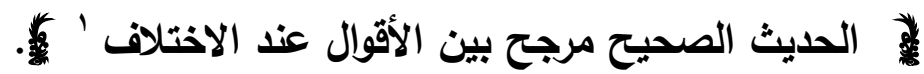
المبحث الأول: بين يدي القاعدة: المطلب الأول: تعريف قواعد الترجيح. قبل التعريف بقواعد الترجيح مركبة لابد من الوقوف على معنى كل من شطري التركيب مفرداً. القواعد في اللغة:

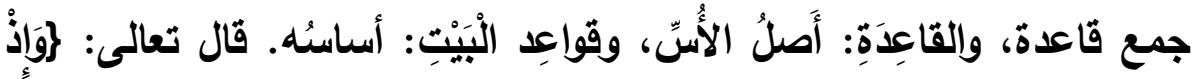

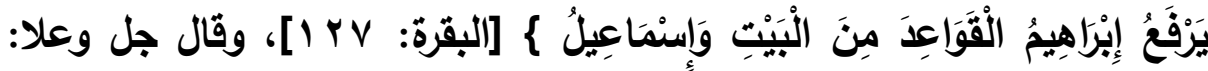

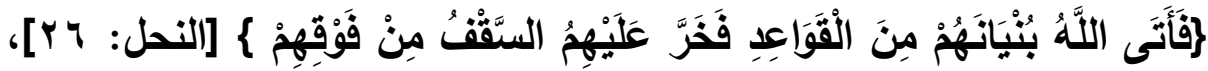

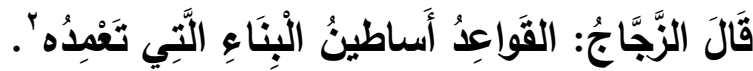

$$
\text { وفي الاصطلاح: }
$$

قال الجرجاني: القاعدة: هي قضية كلية منطبقة على جميع جزئياتهاّا. وقال غيره: قضايا أغلبية. الترجيح في اللغة:

تلل على الثثلَ في الوزن، والتفضيل، قال الجوهري: رَجَحَ الميزانُ يَرَجَحُ

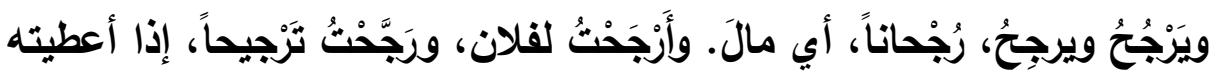
راجحاً .

1 انظر : قواعد الترجيح عند المفسرين - للاكتور حسين بن علي الحربي بغير صيغته

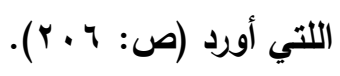

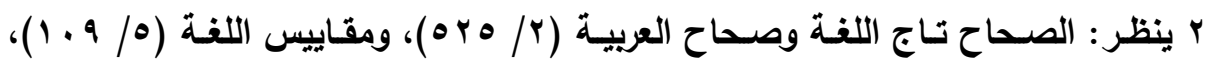

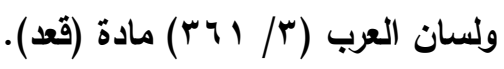

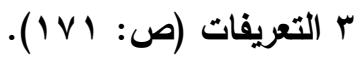


قال ابن فارس: (رجح) الراء والجيم وإحاء أصل واحل، يدل على رزانة

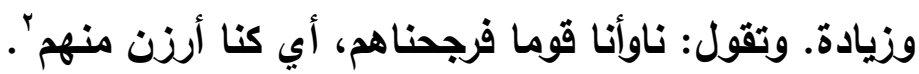
وفي الاصطلاح:

قال الجرجاني: إثبات مرتبة في أحد الاليلين على الآخرّ".

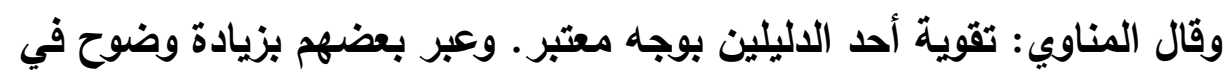

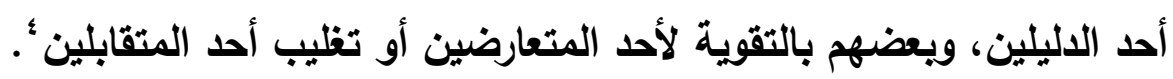

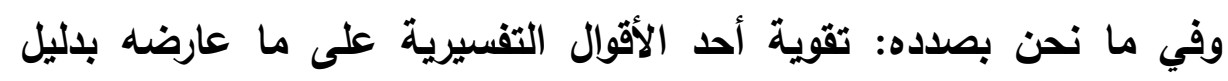
معتبر . أما تعريف قواعد الترجيح مركباً في رأي الباحث: قضايا وضوابط أغلبية نقوي بها ونرجح أحد الأقوال التفسيرية على ما خالفه. المطلب الثاني: صورة القاعدة.

صورة القاعدة:

إذا ورد خلاف المفسرين في تفسير آية من القرآن، وكان لهم فيها عدة أقوال،

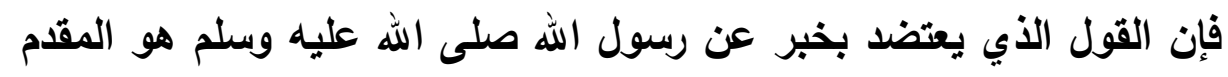

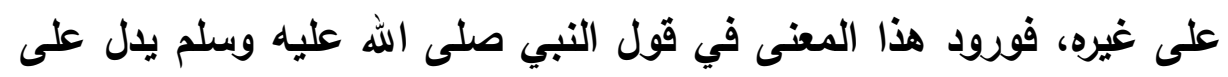

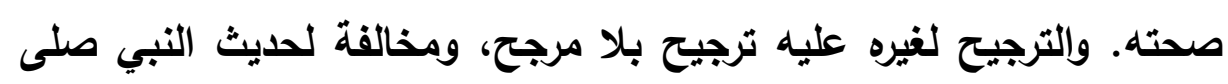

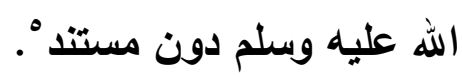

أما إذا اعتضد كل قول بسنة، أو بقرآن فالترجيح يكون بغير هذه القاعدة.

$$
\begin{aligned}
& \text { ا ينظر: الصحاح تاج اللغة وصحاح العربية (1/ ع ؟ب)(رجح) بتصرف. }
\end{aligned}
$$

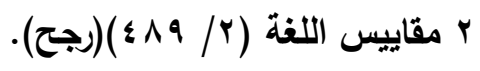

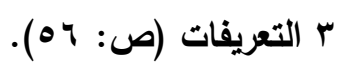

$$
\begin{aligned}
& \text { ؛ التوقيف على مهمات التعاريف (ص: (ص) (9). }
\end{aligned}
$$

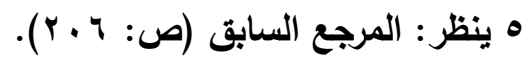




$$
\begin{aligned}
\text { اعتمد هذه القاعدة كثير من المفسرين، الأول: أقوال العلماء في الثاني: التطبقات على القاعدة: هؤلاء: القاعدة: }
\end{aligned}
$$

الإمام الطبري: كثيراً ما نراه يرجح بهذه القاعدة، فمن ذلك قوله في معرض هن

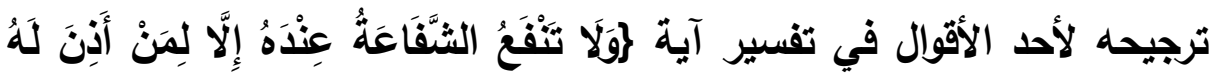

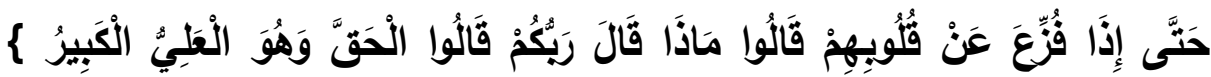
[سبأ: rrr] "وأولى الأقوال في ذلك بالصواب القول الأي ذكره الشعبي عن ابن

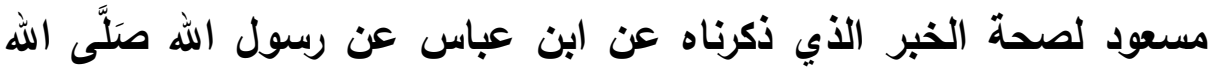
عَلَيْهِ وَستََّّم بتأييده. وإذ كان ذلك كنلك، فمعنى الكلام: لا تنفع الثفاعة عنده إلا لمن أذن له أن يشفع عنده، فإذا أذن الله لمن أذن له أن يشفع فزع

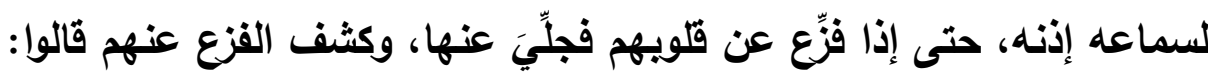

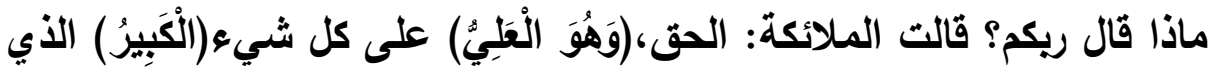

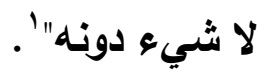

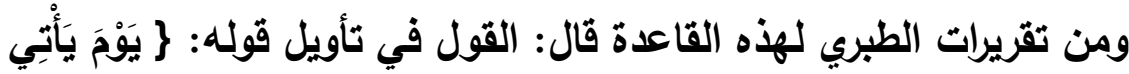

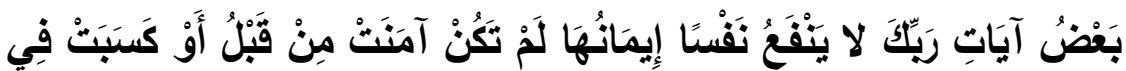

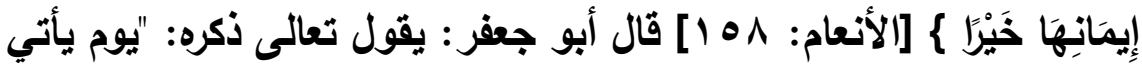
بعض آيات ربك"، لا ينفع من كان قبل ذلك مشركًا بالله، أن يؤمن بعد مجيء تلك الآية.

وقيل: إن تلاك الآية التي أخبر الله جل ثناؤه أن الكافر لا ينفعه إيمانه عند مجيئها: طلوعُ الشمس من مغربها. وسرد العديد من الأحاديث والآثار منها حديث أبو هريرة قال، قال رسول الله صلى الله عليه وبلم: 》 لا تقوم الساعة حتى تطلع الشمس من مغريها. قال: 


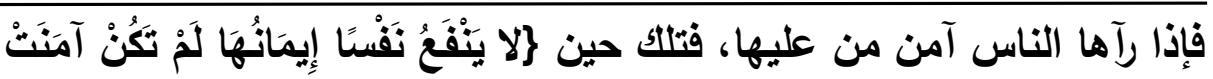

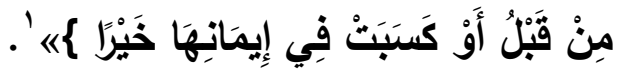
ثم ذكر قولاً آخر قال:

وقال آخرون: بل ذلك بعض الآيات الثلاثة: الدابة، ويأجوج ومأجوج، وطلوع

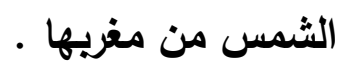

كذلك في هذا القول استدل بالعديد من الأحاديث والآثار، ثم قال: قال أبو جعفر: وأولى الأقوال بالصولب في ذلك، ما تظاهرت به الأخبار عن رسول الله صلى الله عليه وسلم أنه قال:"ذلك حين تطلع الشمس من مغربها". ومن المفسرين أبو جعفر التحاس عند تفسير سورة الفتح قال: مَعْنَى كِإنَّا

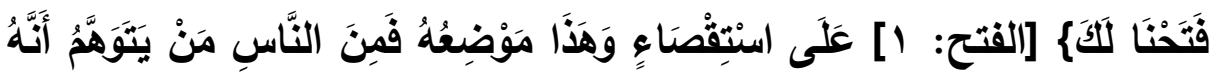

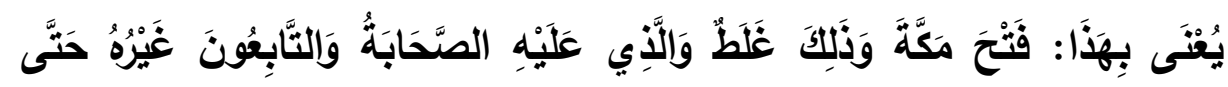

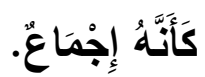

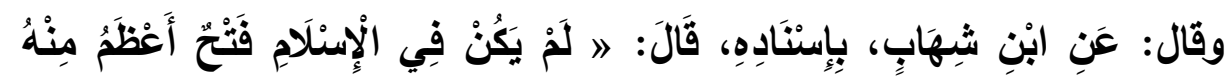

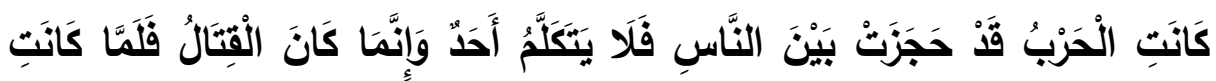

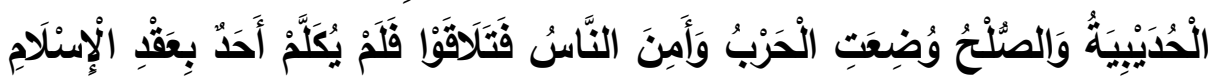

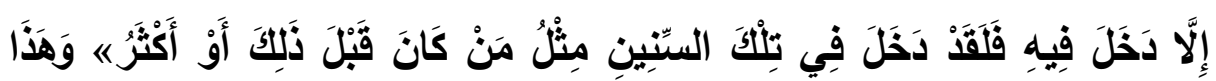

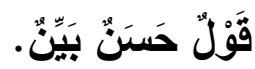

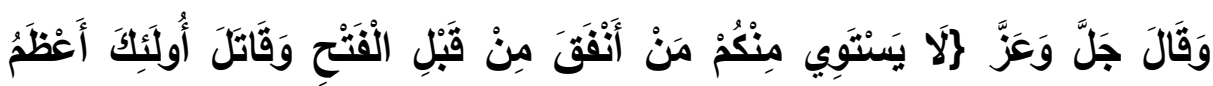

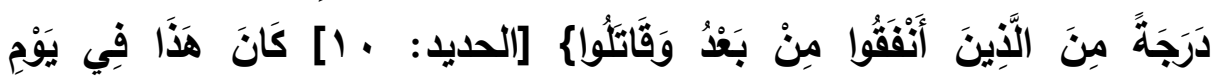

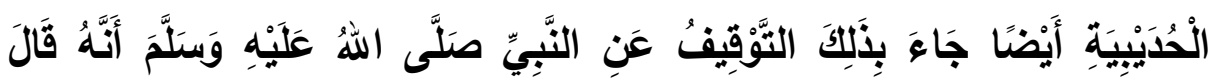

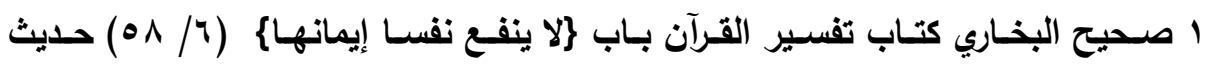




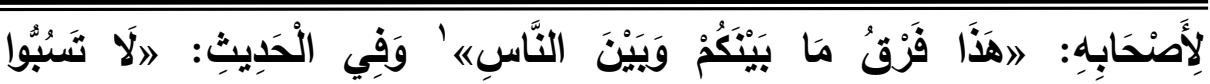

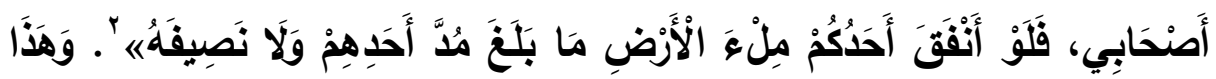

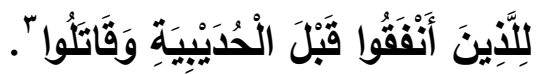

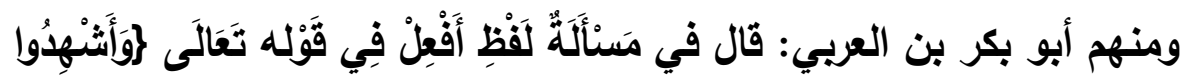

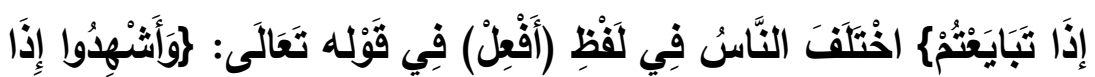

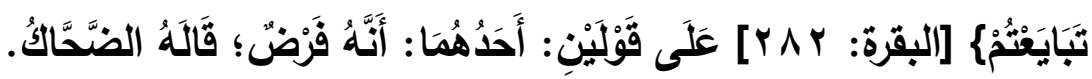

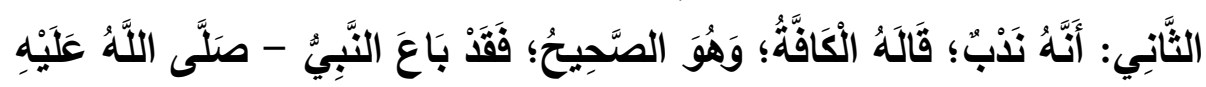

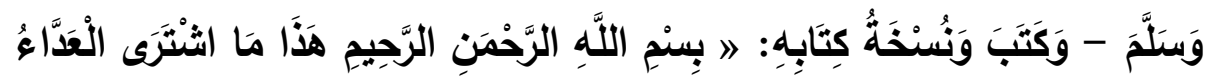

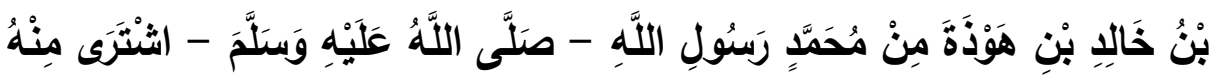

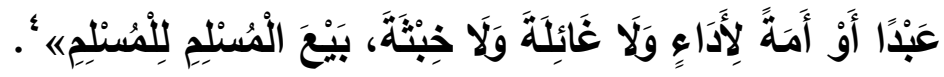

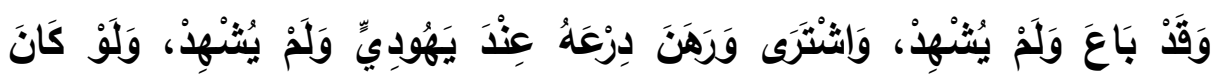

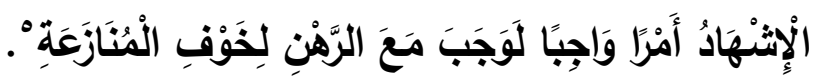
ومنهم القاضي ابن عطية قال: وقوله تعالى:

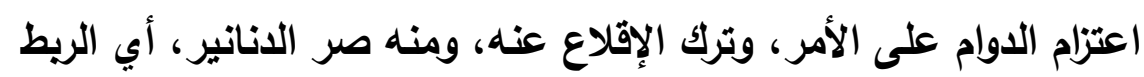
عليها، ومنه قول أبي السمال قعنب العدوي: علم الله أنها مني صرى.

الم الم أجده لا مرفوعأ ولا موقوفاً ولا مقطوعاً.

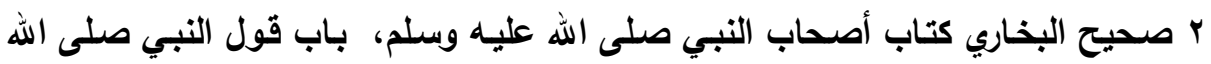

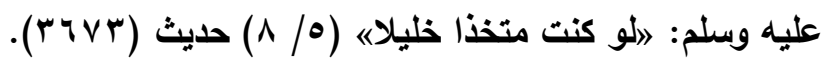

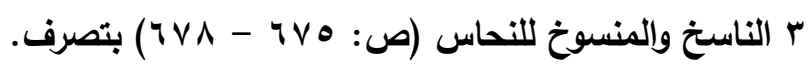

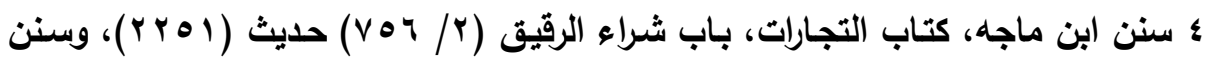

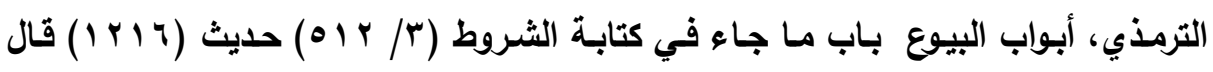

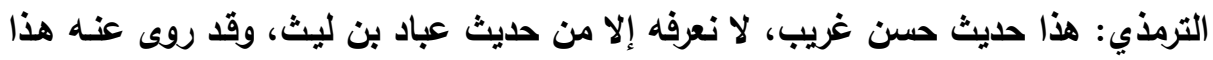

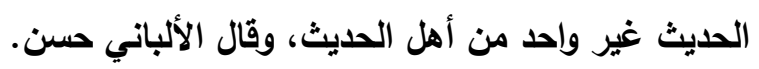

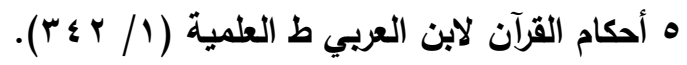


يريد: عزيمة. فالإصرار اعتزام البقاء على الاتب، ومنه قول النبي عليه

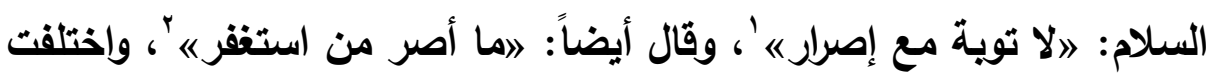
عبارة المفسرين في الإصرار، فقال قتادة: هو الذي مضي قدماً في الذنب لا تنهاه مخافة الله. وقال الحسن، إتيان العبد الأنب هو الإصرار حتى يتوب، وقال مجاهد: \} لم يصروا \{ معناه: لم يمضوا وقال السدي: 》الإصراره هو ترك

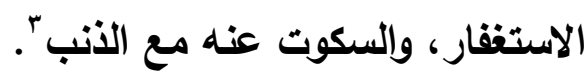

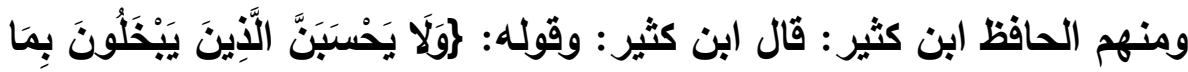

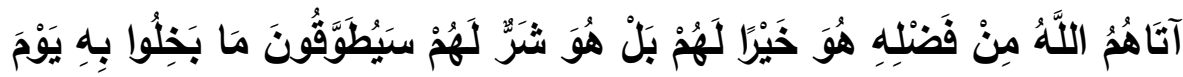

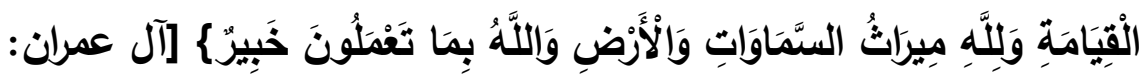
ـ1 1 ] أي: لا يحسبن البخيل أن جمعه المال ينفعه، بل هو مَضّرة عليه في

$$
\text { دينه - وريما كان - في دنياه. }
$$

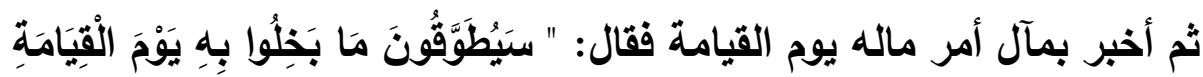

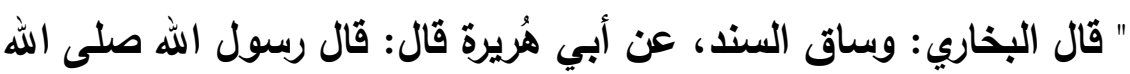

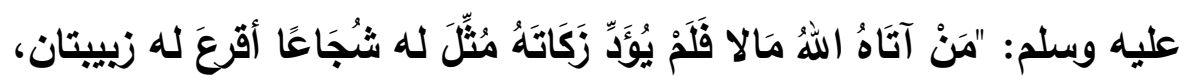

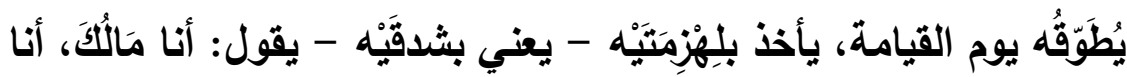

الم أجده من كلام النبي صلى الله عليه وسلم ولا من كلام الصحابة والتابعين، لذا نسبه

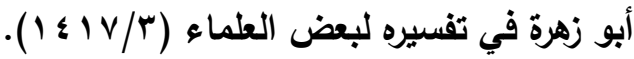

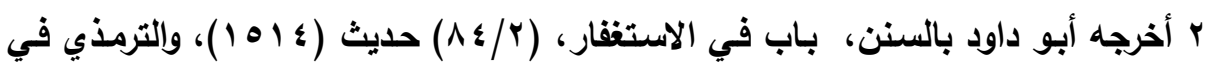

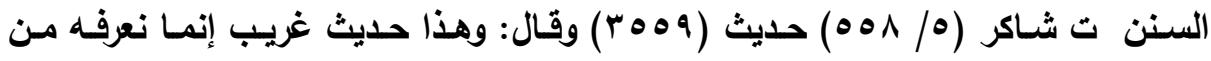
حليث أبي نصيرة، وليس إسناده بالقوي، وضعفه الألباني.

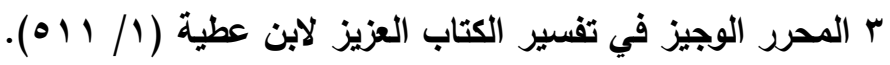




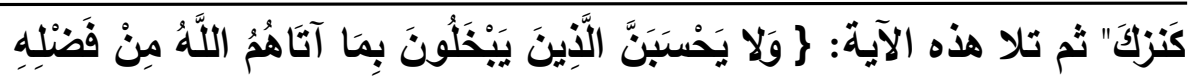

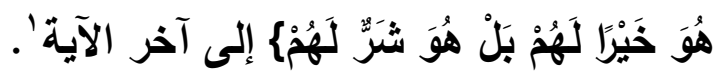

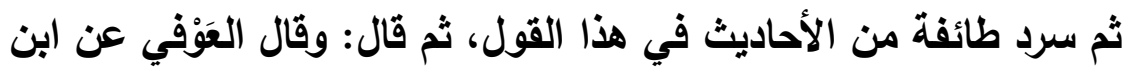

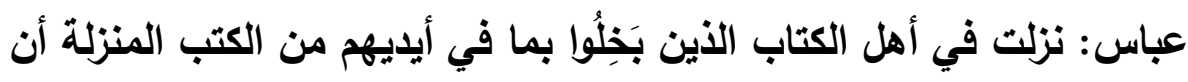

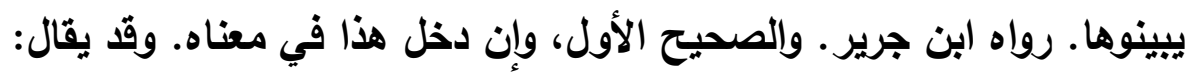

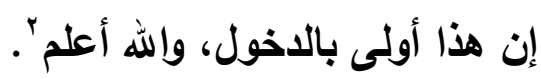
ومنهم الألوسي: كثيراً ما يستعمل هذه القاعدة في تأييد اختياره وترجيحه فعند

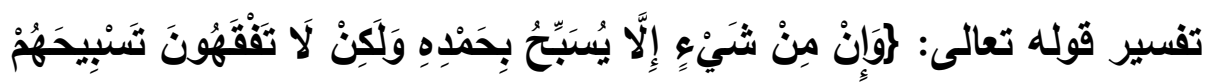

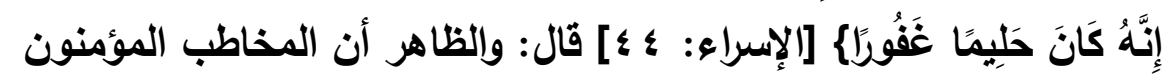

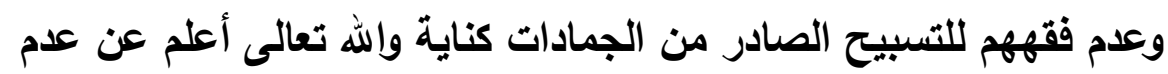
العمل بمقتضى ذلك فإن الإنسان لو تيقظ حق التيقظ إلى أن النملة والبعوضة البمانة وكل ذرة من ذرات الكون يقد الله تعالى وينزهه ويشهد بحلاله وكبريائه

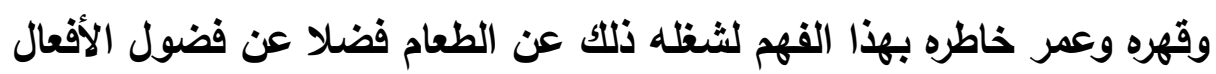

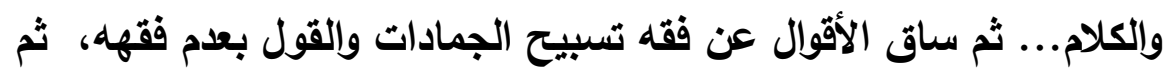

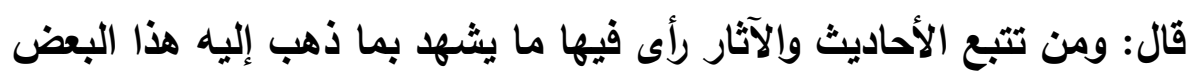
شهادة لا تكاد تقبل التأويل فقد صح سماع تسبيح الحصا في كفه صلّى الله

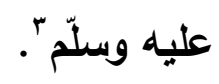

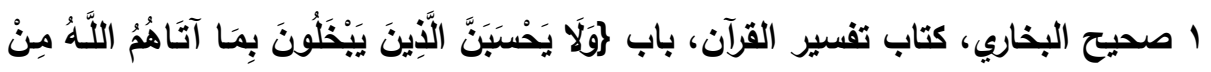

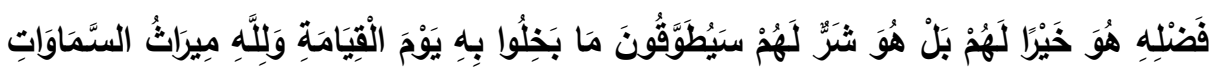

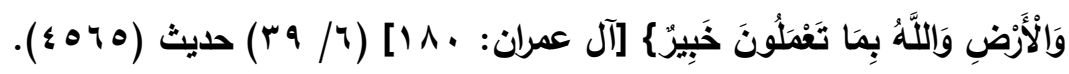

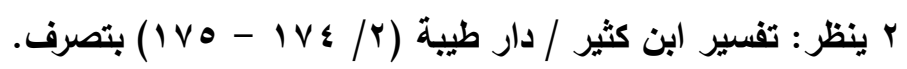

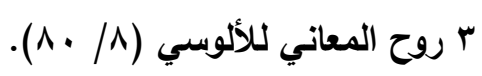


ومنهم الطاهر ابن عاشور: فقد قرر هذه القاعدة في تفسيره ومن ذلك مثلاً

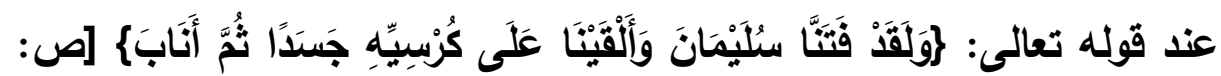

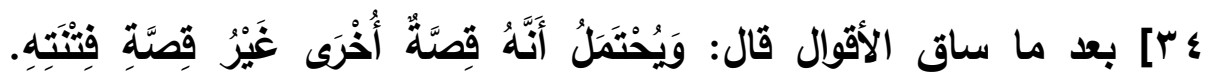

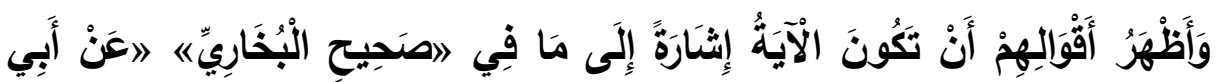

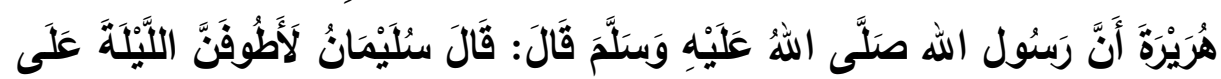

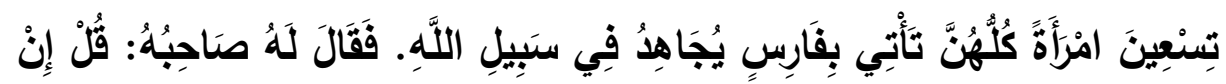

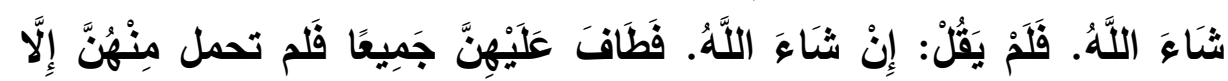

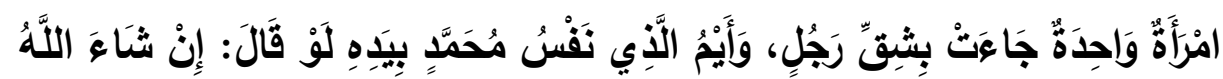

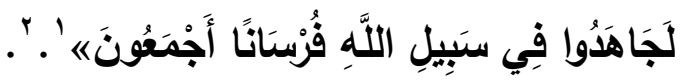

ا صحيح البخاري، كتاب الإيمان والنذور، باب: كيف كانت يمين التبي صلى الله عليه

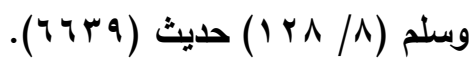

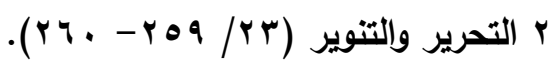


المطلب الثاني: الأمثلة التطبيقية على القاعدة:

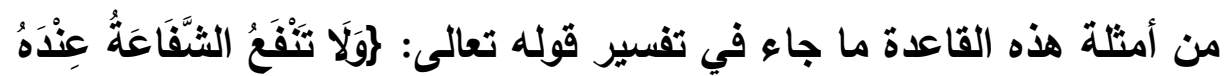

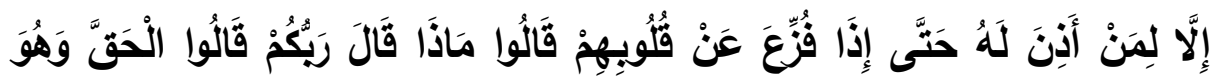

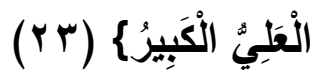

قال الطبري: اختلف أهل التأويل في الموصوفين بهذه الصفة من هم؟ وما

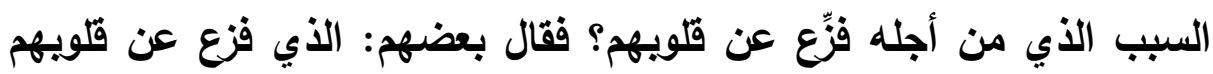

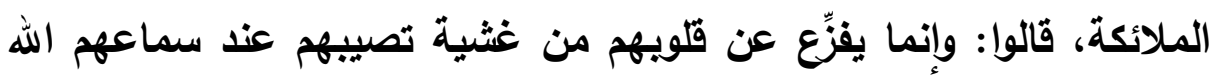

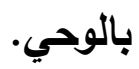
ثم ذكر لهذا القول عدة آثار منها ما رواه الثعبي قال: قال ابن مسعود في

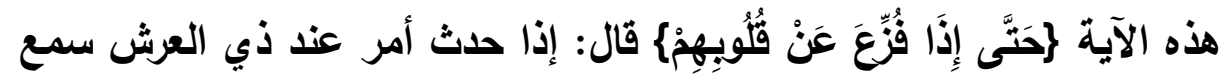

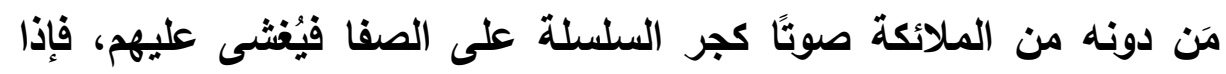

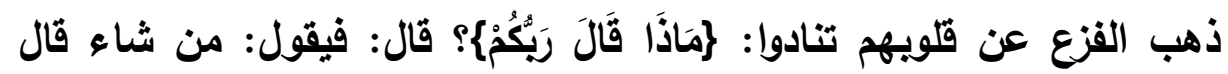

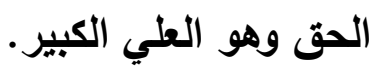
وكنلك ما أثر عن مسروق قال: إذا حدث عند ذي العرش أمر سمعت الملائكة

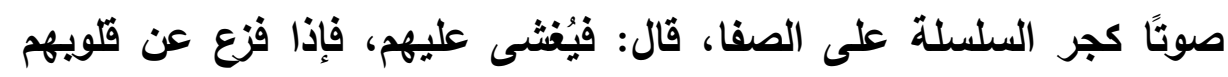
قالوا: ماذا قال ريكم؟ قال: فيقول من شاء الله الحق وهو العلي الكبير.

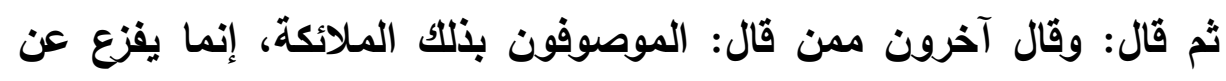

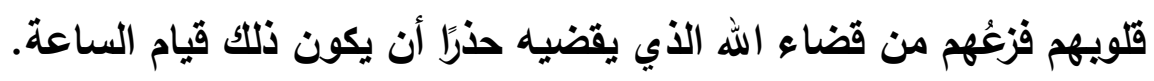

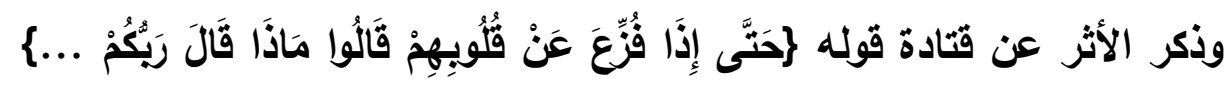

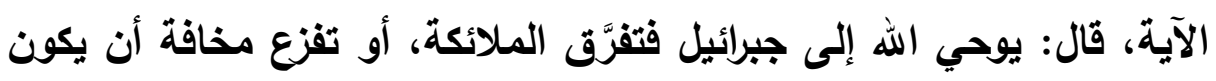

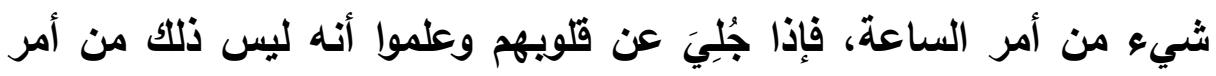

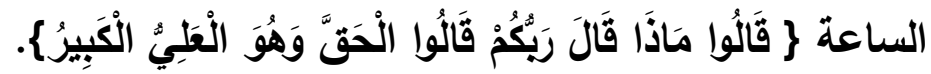


وقال: قال آخرون: بل ذلك من فعل ملائكة السماوات إذا مرث بها المعقبّات فزعًا أن يكون حدث أمر الساعة.

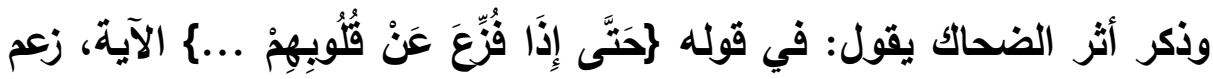

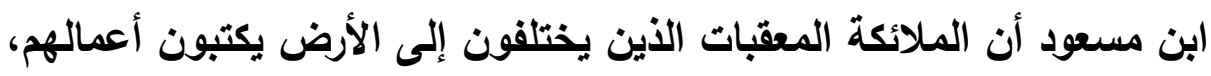

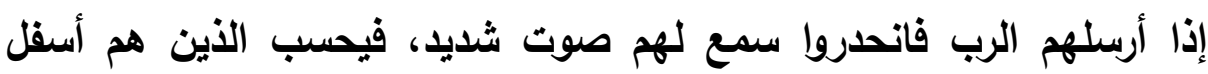

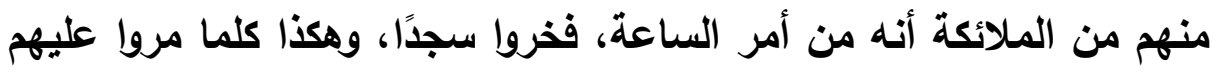
يفعلون ذلك من خوف ريهر. والقول الرابع: قال: وقال آخرون: بل الموصوفون بذلك المشركون، قالوا: وإنما

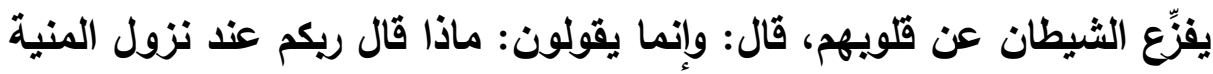
بهم.

وساق قول ابن زيد، في قوله:

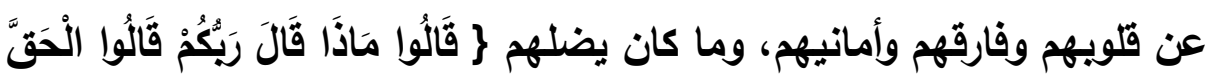

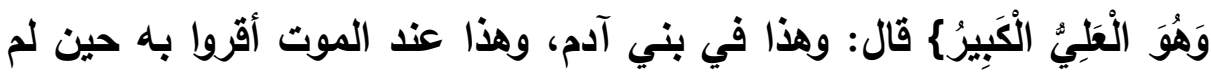

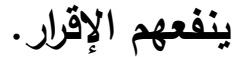

قال الطبري بعد سرد هذه الأقوال معملاً هذه القاعدة: وأولى الأقوال في ذلك الكّال بالصواب القول الذي ذكره الشعبي عن ابن مسعود لصحة الخبر الذي ذكرناه

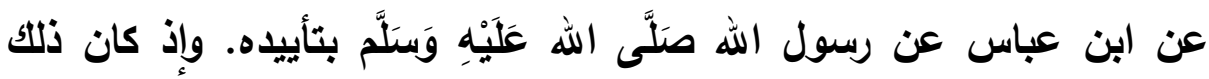
كذلك، فمعنى الكلام: لا تنفع الثفاعة عنده إلا لمن أذن له أن يشفع عنده،

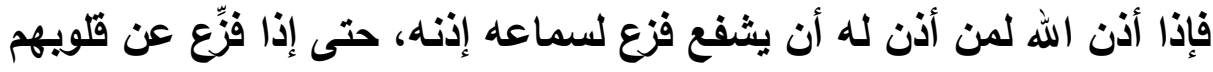

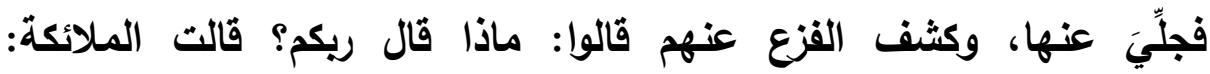

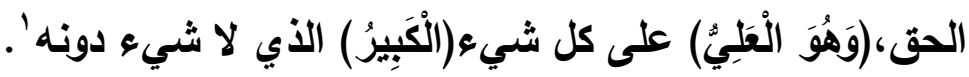

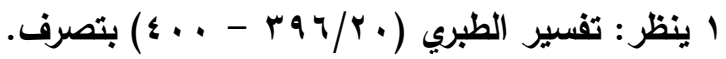




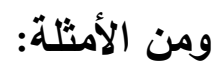

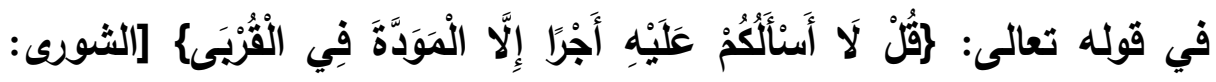

[rr

قال النحاس: في هذه الآية أريعة أقوال:

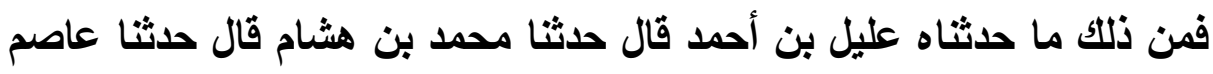
بن سليمان عن جويير عن الضحاك عن ابن عباس قل لآ أسئلكم عليه أجرا قال لا أسأكم على الإيمان جعلا إلا أن تودوني لقرابتي وتصدقوني وتمنعوا

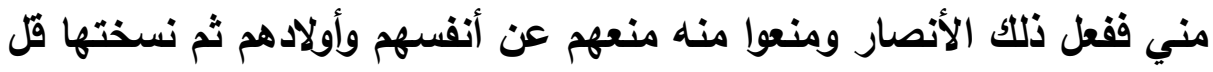

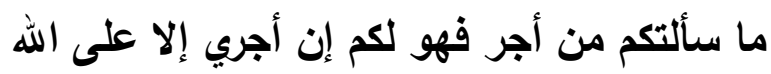

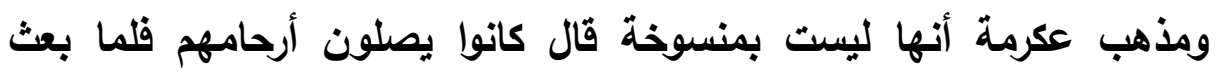

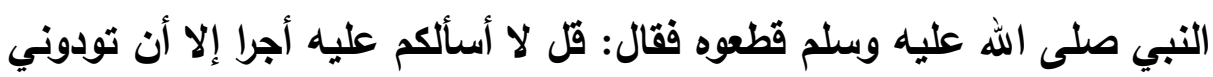
وتحفظوني لقرابتي ولا تكنبوني، وفي رواية قيس عن الأعش عن سعيد بن

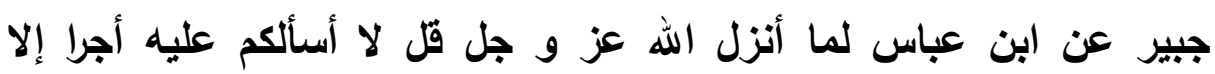
المودة في القربى قالوا يا رسول الله من هؤلاء الذين نود بهم قال علي وفاطمة وولدهما صلوات الله عليهم.

والقول الرابع من أجمعها وأبينها كما قرئ على عبدالله بن الصقر بن نصر عن الهن

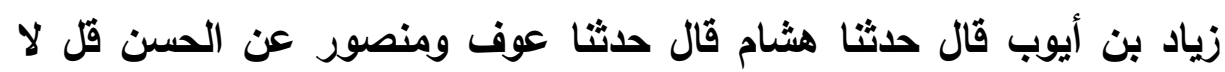
أسأكم عليه أجرا إلا المودة في القربى قال التقرب إلى الله عز و جل والثام التودئ

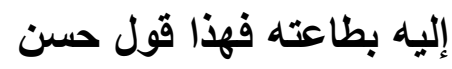


ويدل على صحته الحديث المسند عن رسول الله صلى الله عليه و سلم، عن

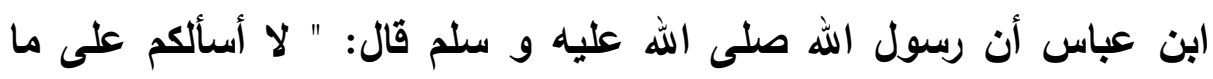

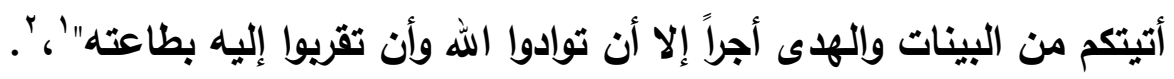

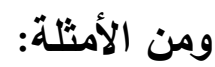

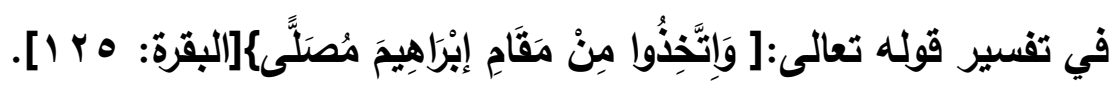

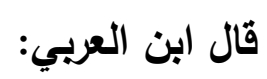

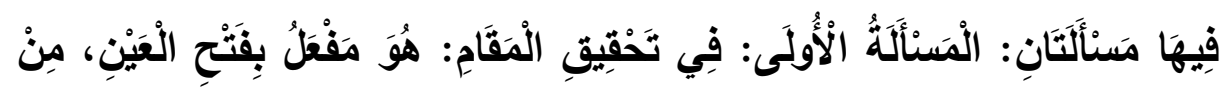

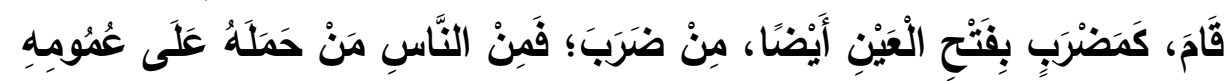

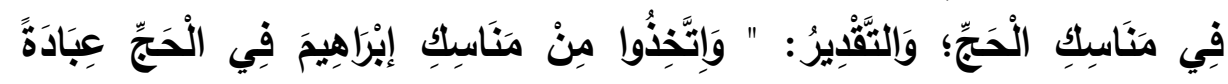
وَقَُْْوَةًا..

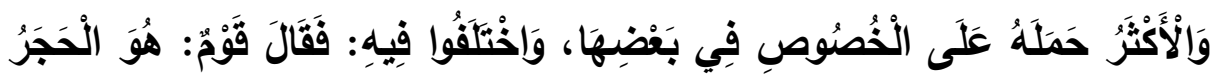

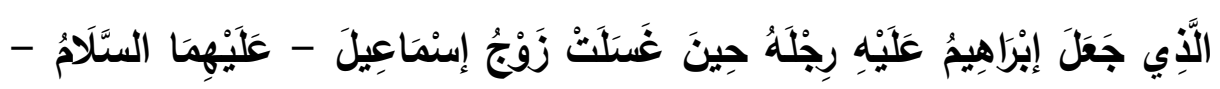
رَأْسَةُه.

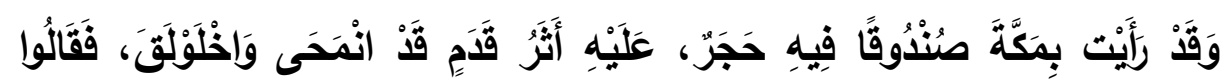

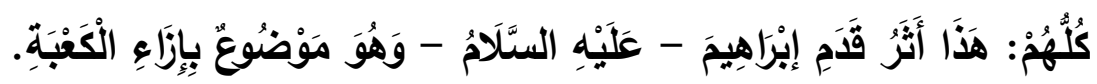

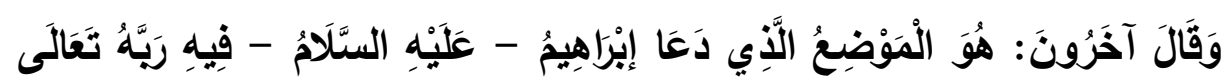
حِينَ اسْنَوَدَعَ ذُرِيَتَتَهُ.

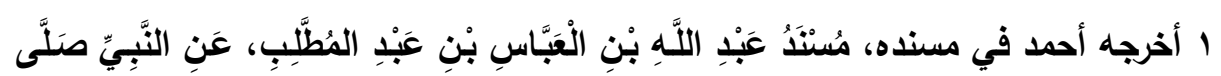

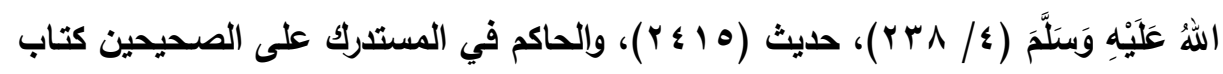

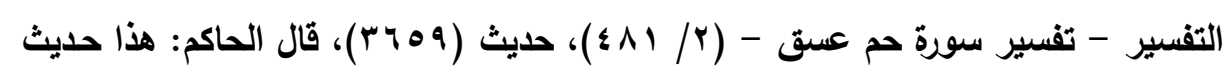

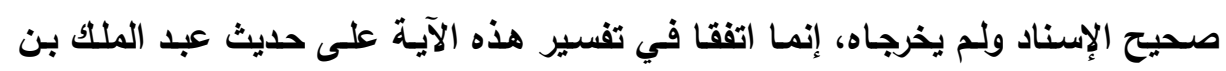

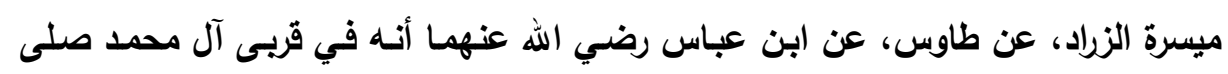
الله عليه وسلم، ووافقه الذهبي.

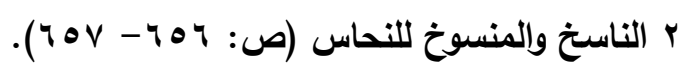


فَمَنْ حَمَلَهُ عَلَى الْعُوُومِ قَالَ: مَعْنَاهُ كَمَا قََََمَنَا مُصَلَّى: مَلْعَى أَبْ مَوْضِعًا

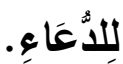

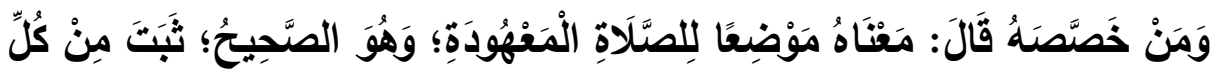

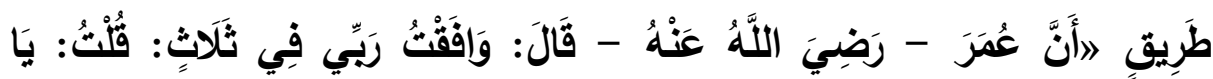

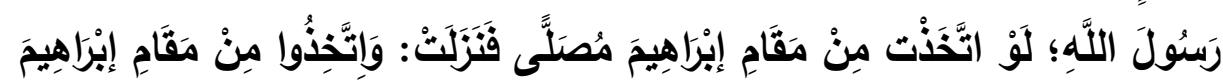

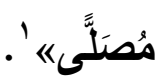

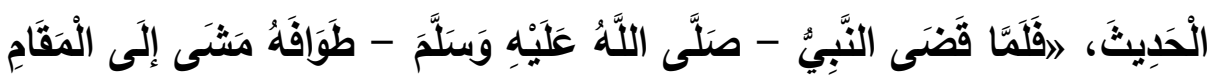

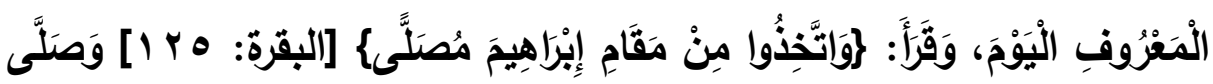

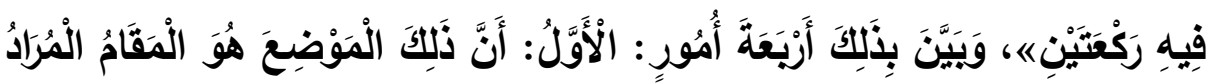
فِي الْآيَةِه.

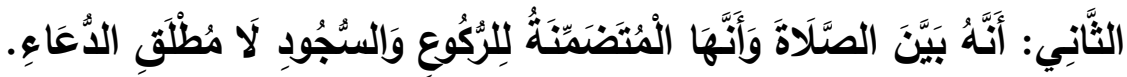

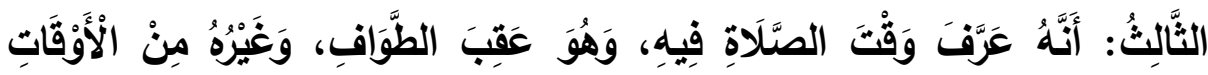

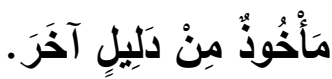

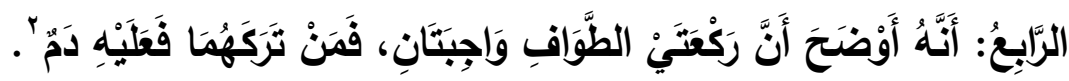

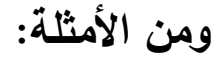
قال ابن العربي في مَسنأَلَة الْمَمْسُوخِ هَلْ يَنْسِلُ أَمْ لَا؟

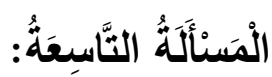

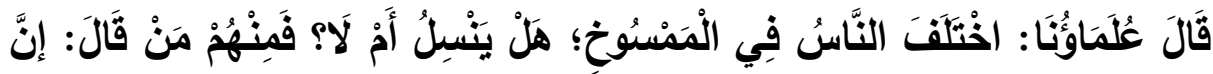

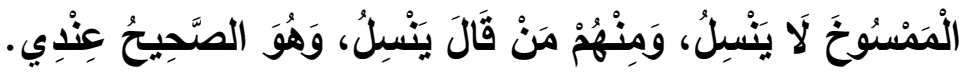

1 متفق عليه، البخاري - كتاب الصلاة - باب ما جاء في القبلة - حديث( ب + ـ)، ومسلم

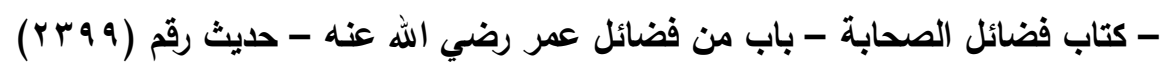

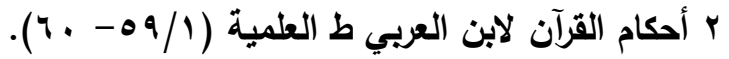




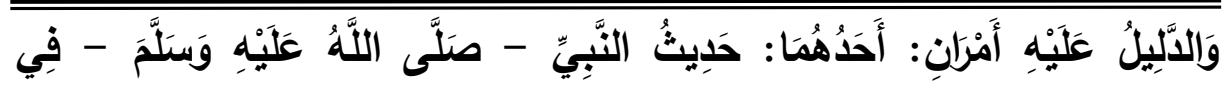

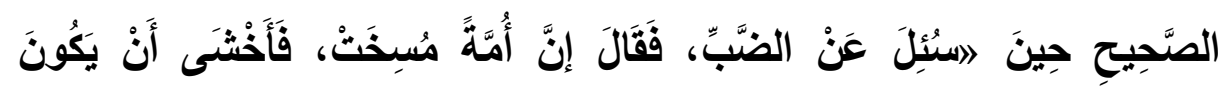

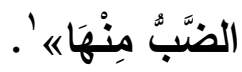

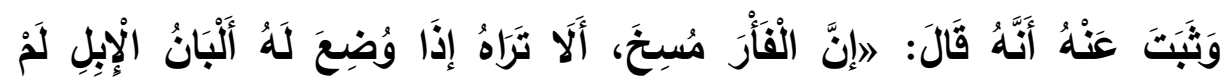

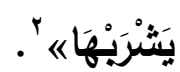

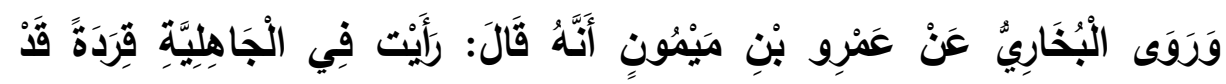

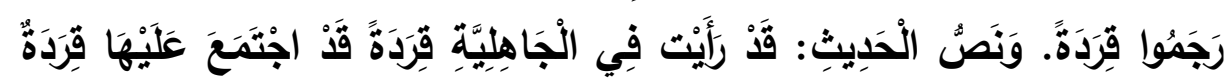

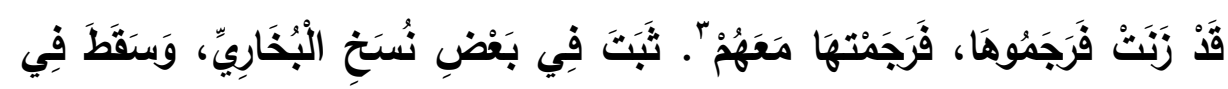

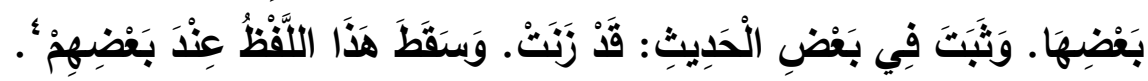

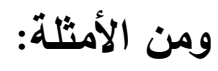

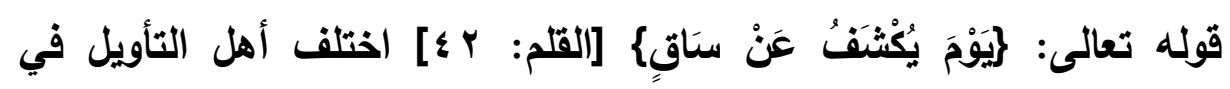
تفسير هذه الآية على قولين:

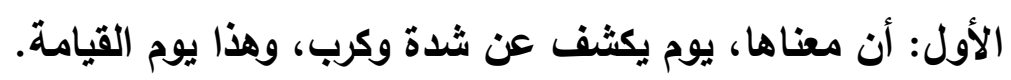

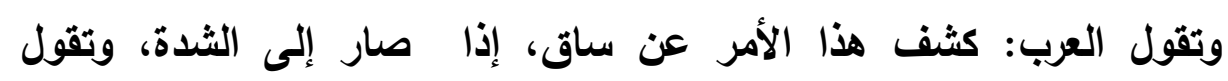
وشمرث الحرب عن ساقها، أي إذا اشتثات. قال ابن عباس رضي الله عنهما عن هذه الآية: يكثف عن أمر عظيم، كقول

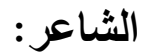

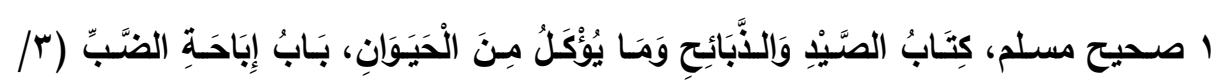
19 1901) (1901).

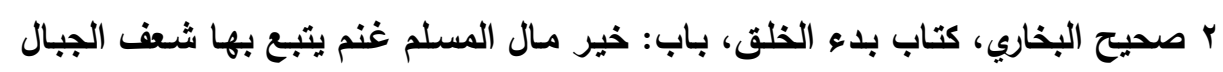

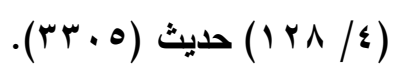

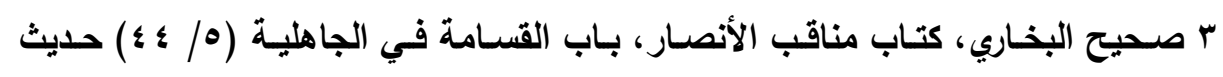

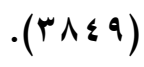

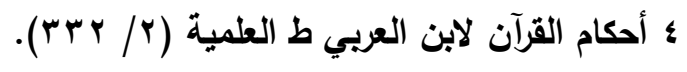




$$
\text { وقامت الحرب بنا على ساق' }
$$

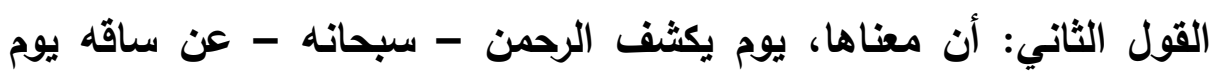

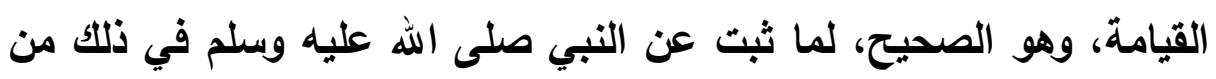

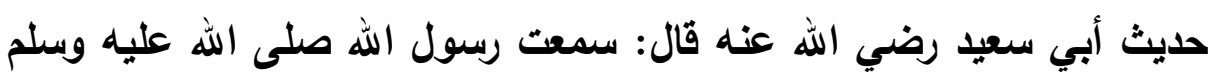

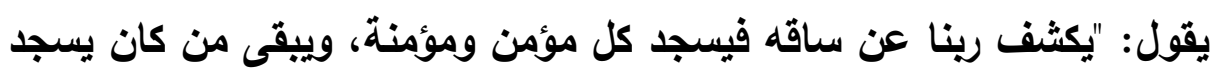

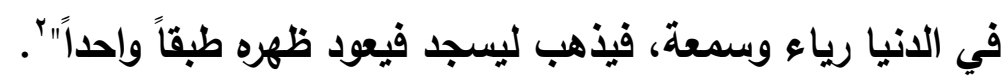
قال الثوكاني مقراً هذه القاعدة:

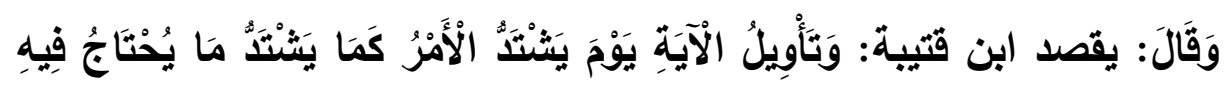

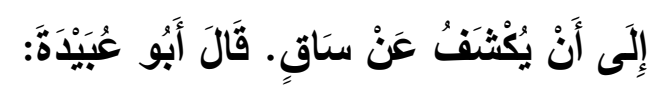

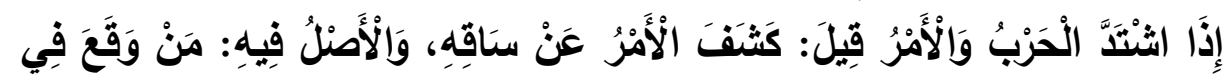

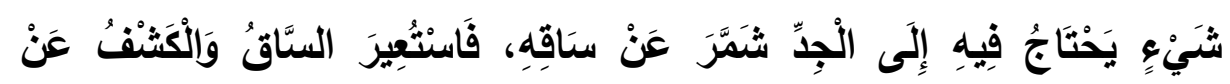

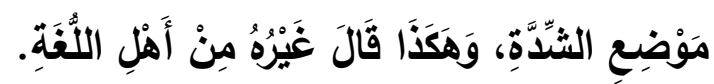

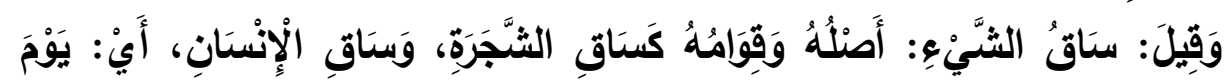

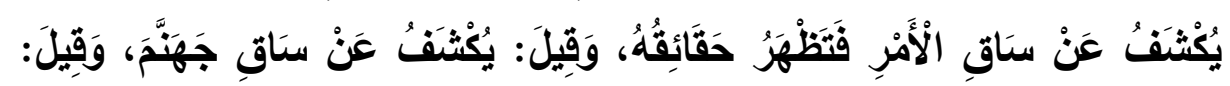

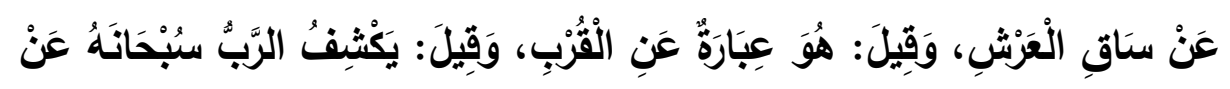

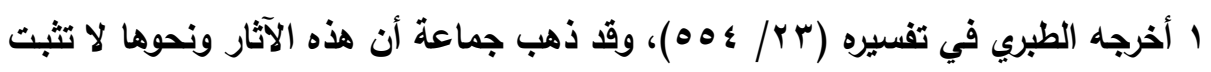

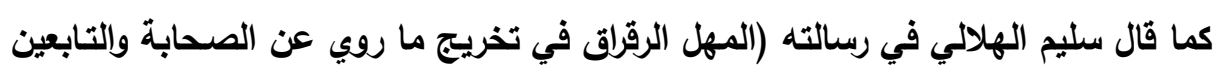

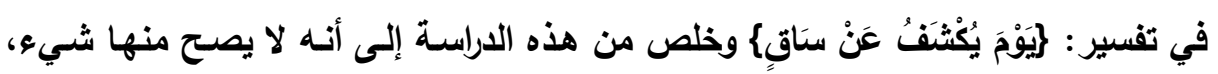

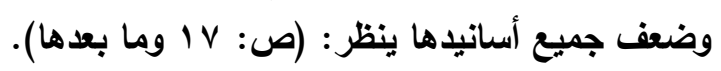

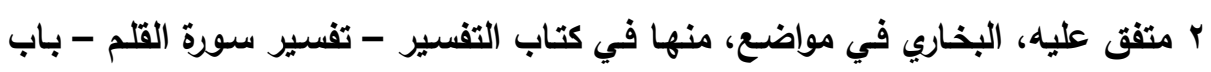

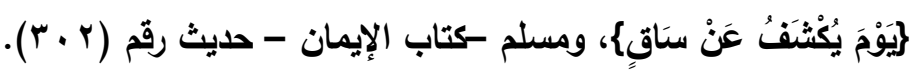




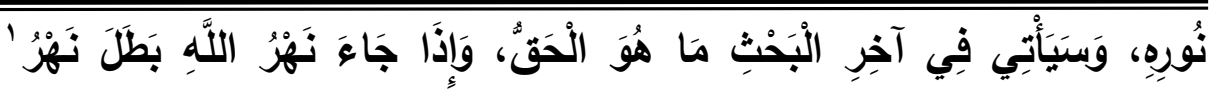

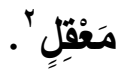
وذكر الخلاف والآثار في ذلك ثم قال:

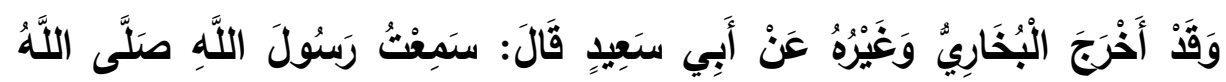

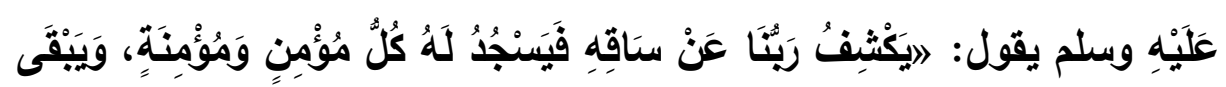

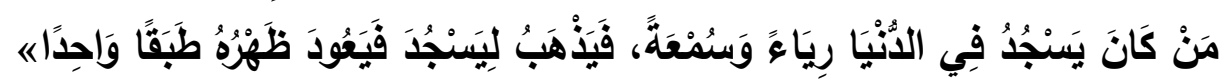

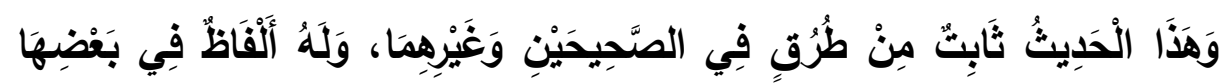

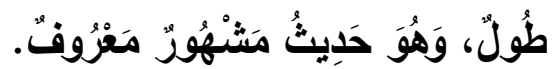
ثم قال:

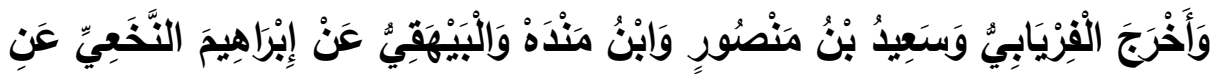

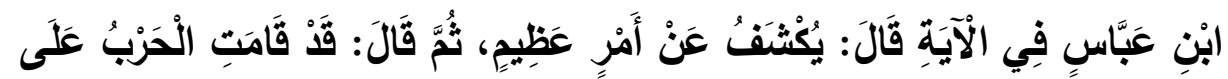

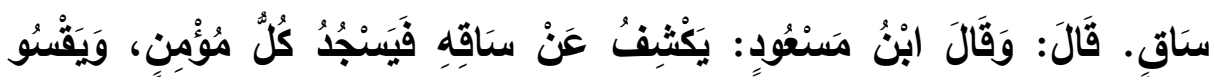

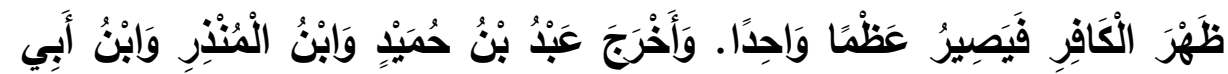

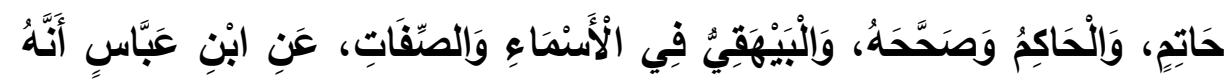

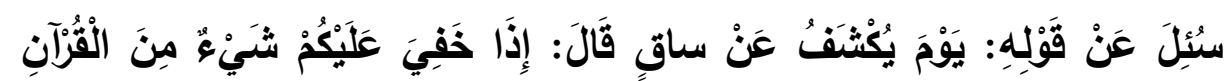

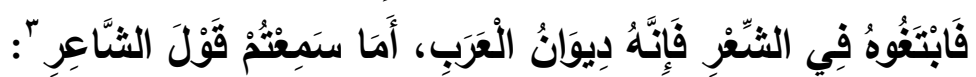

1 مثل معروف، والنهز منسوب للصابي الجليل معقل بن يسار رضي الله عنه، أمر عمر

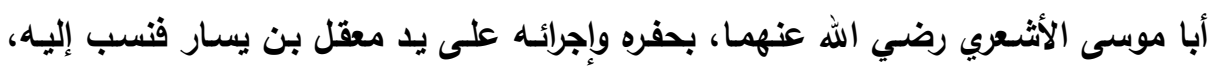

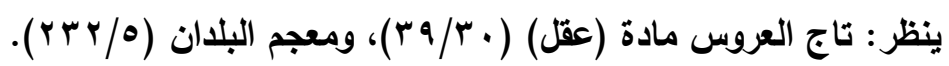

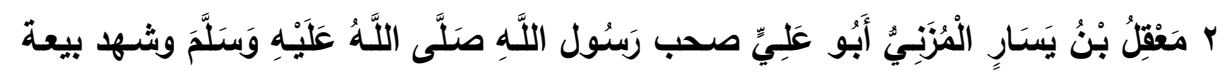

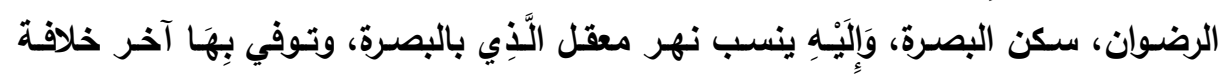

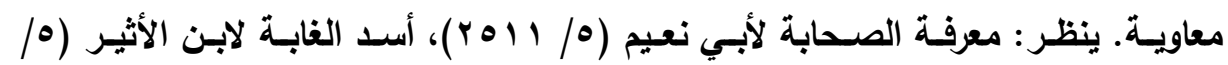
S r r r r البيت لحاتم الطائي. 


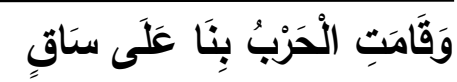

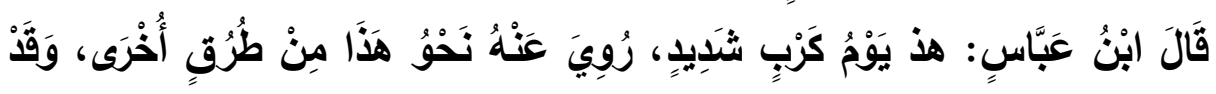

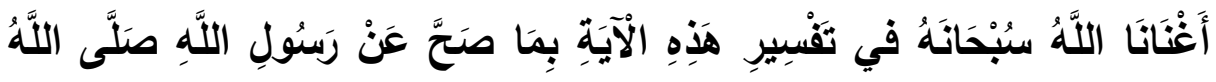

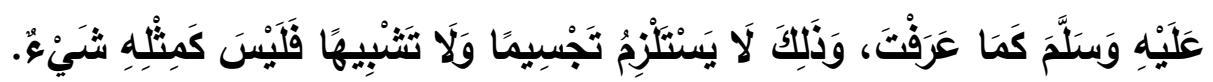

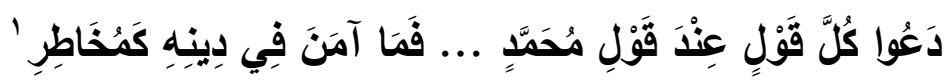

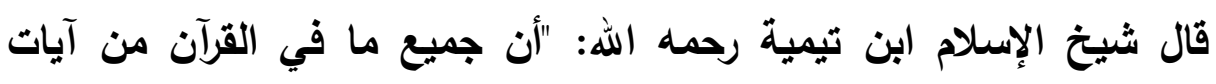

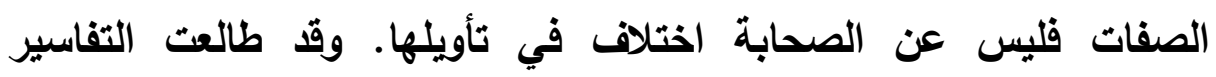

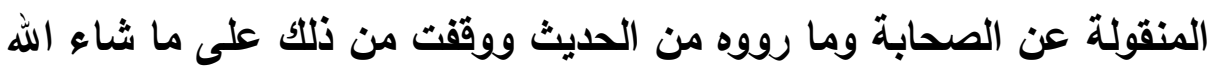

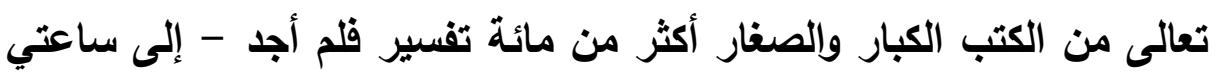
هذه - عن أحد من الصحابة أنه تأول شيئا من آيات الصفات ألهات أو أحاديث

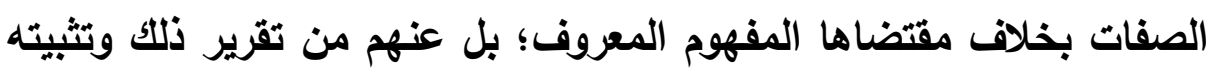

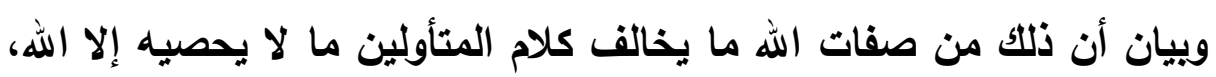

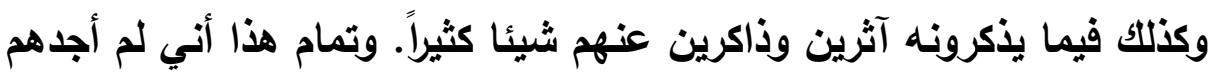

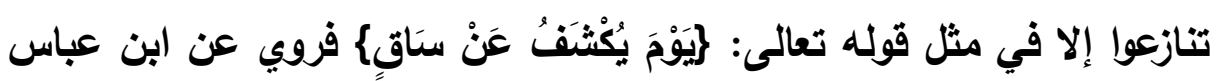

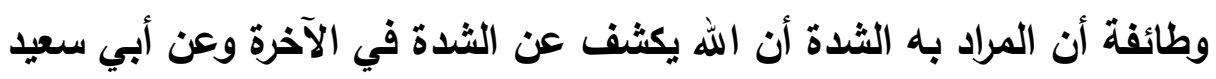

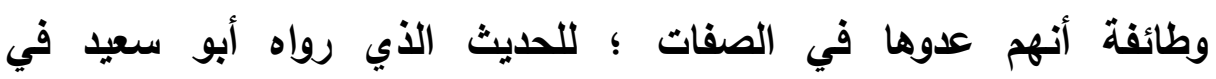

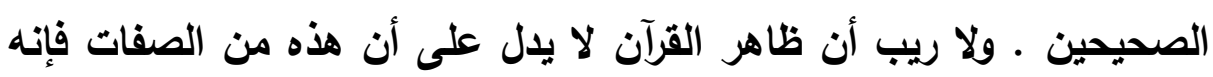

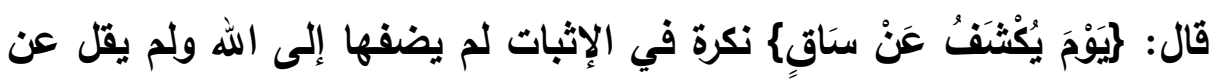

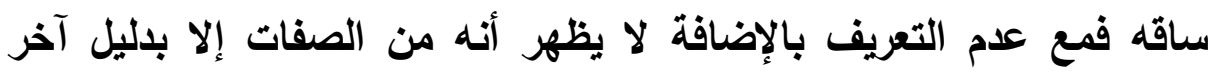

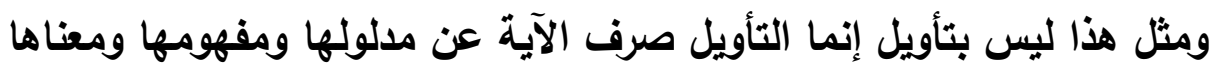
المعروف؛ ولكن كثير من هؤلاء يجطون اللفظ على ما ليس مدلولا له ثم 
يريدون صرفه عنه ويجعون هذا تأويلا، وهذا خطأ من وجهين كما قدمناه غير مرة"' ومن الأمثلة التطبيقية على القاعدة:

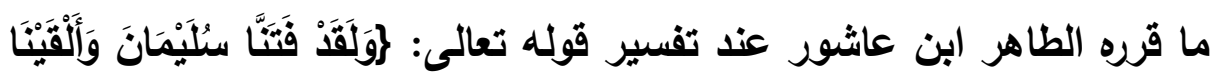

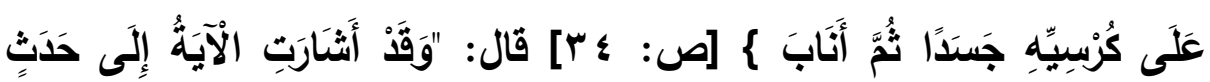

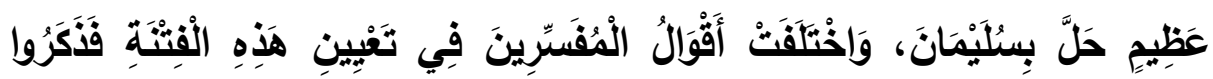

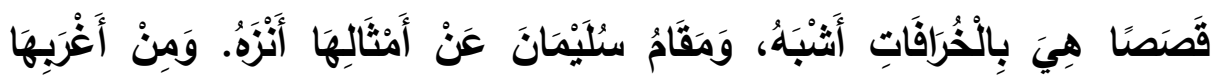

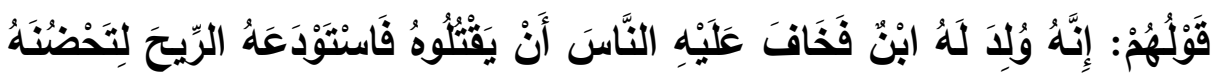

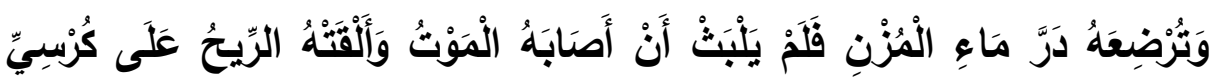

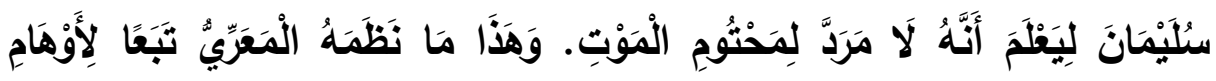

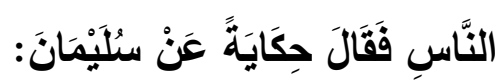

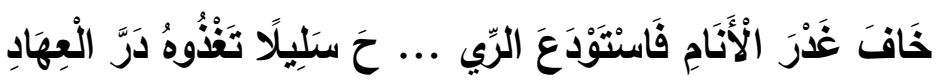

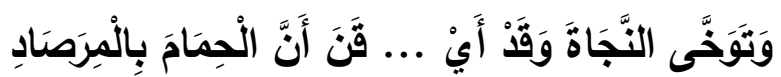

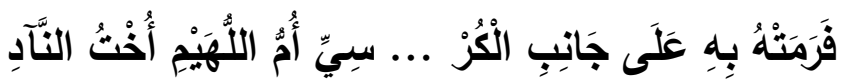

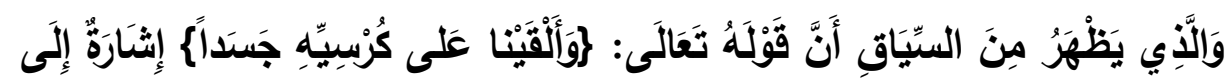

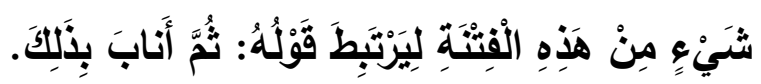

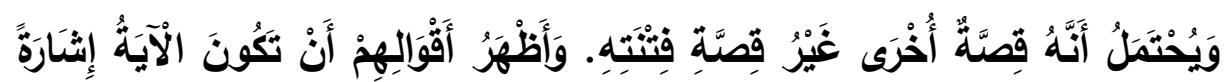

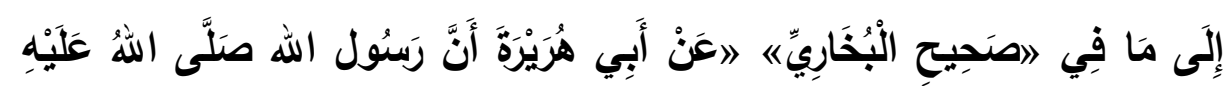

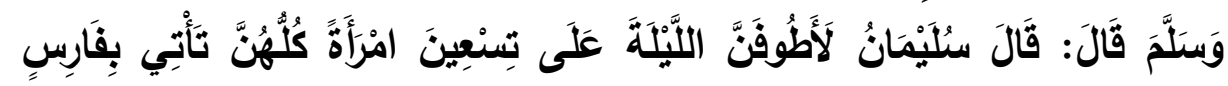

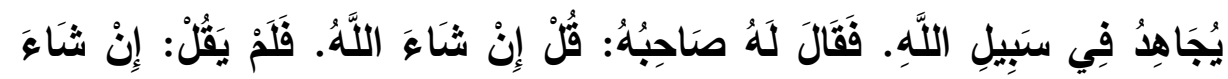

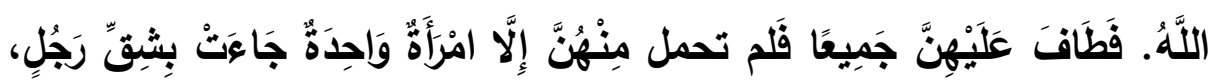




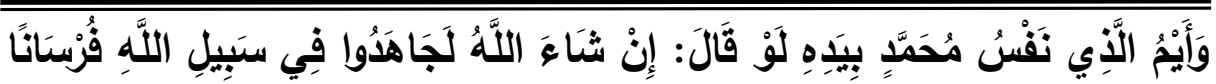

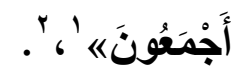
ومن الأمثلة على هذه القاعدة: القداء اختلاف المفسرين في المراد بالفقير والمسكين وأيهما أحسن حالاً من الآخر،

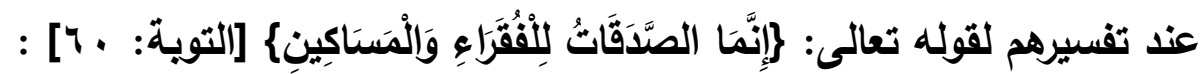
فقيل: الفقير أحسن حالاً من المسكين، قاله: ابن السيّيت، ويونس ابن حبيب، لأن الفقير عنده بعض ما يكفيه ويقيمه، أما المسكين الأي لا شيء له، وواققهم في ذلك من الفقهاء أبو حنيفة، وقال فريق آخر أن المسكين

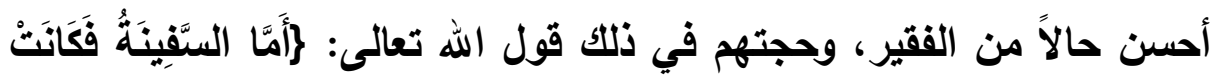

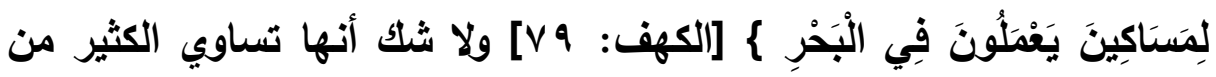
المال، ويؤيده تعوذ النبي صلى الله عليه وسلم من الفقر، مع ما صـح من

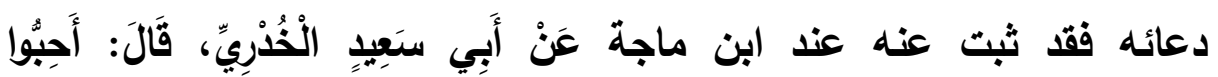

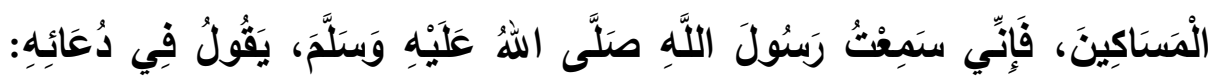

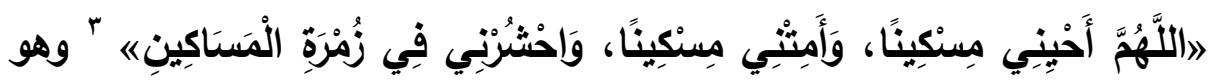

ا صحيح البخاري، كتاب الإيمان والتذور، باب: كيف كانت يمين النبي صلى الله عليه

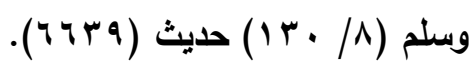

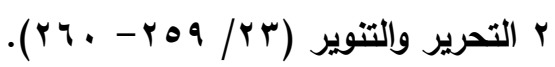

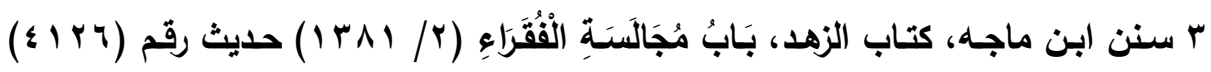

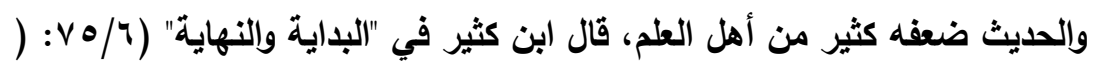

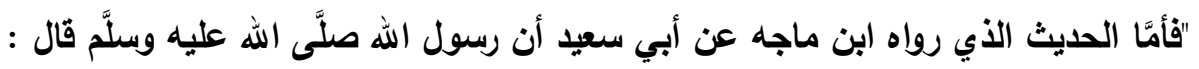

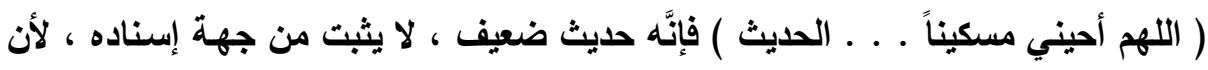

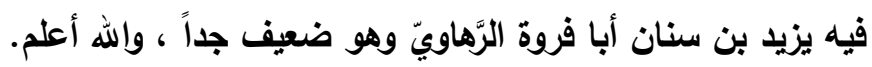

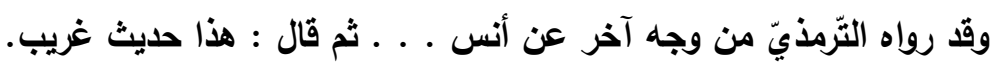


أحد قولي الثافعي وعليه أكثر الصحابة، وقالت طائفة: أن الفقير والمسكين

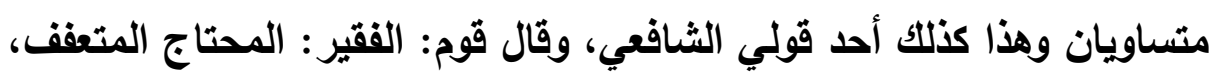
والمسكين: السائل، نسب هذا القول لابن عباس رضي الله عنه، وقد ذكروا

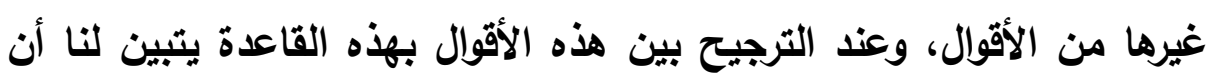

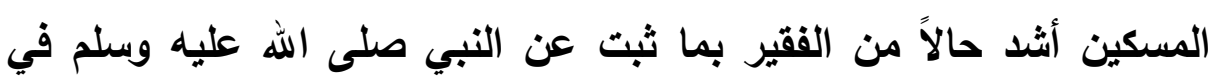
صحيح البخاري ومسلم من حديث أبي هريرة رضي الله عنه أَنَّ رَسُولَ اللَّهِ

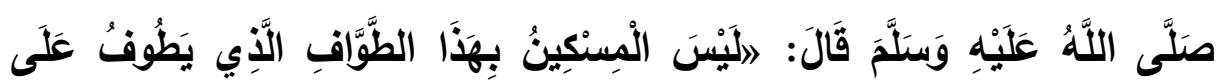

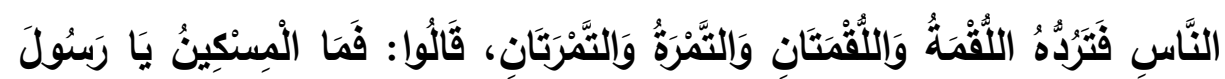

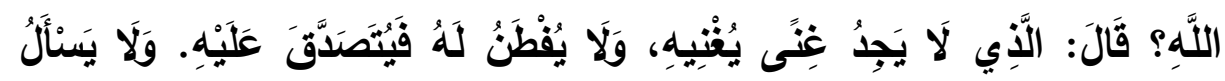
النَّاسَ شَبْيًَا

ومن الأمثلة على هذه القاعدة:

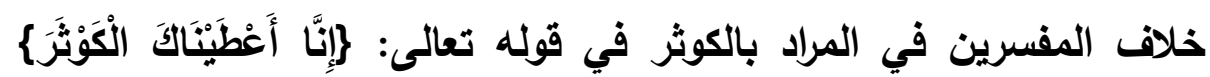

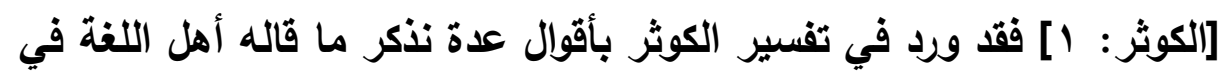

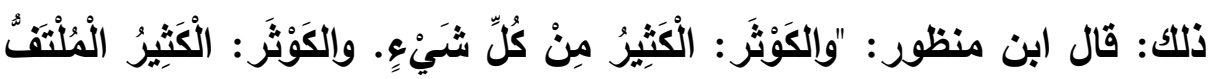

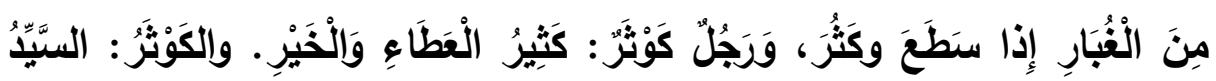

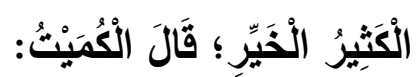

قلت (ابن كثير) : وفي إسناده ضعف ، وفي متنه نكارة ، والله أعلم " انتهى. وَقَّالَ الْحَافِظُ

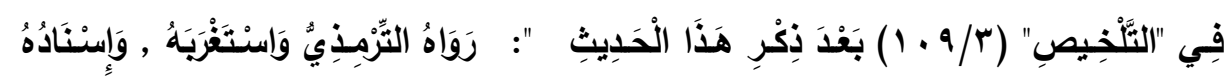

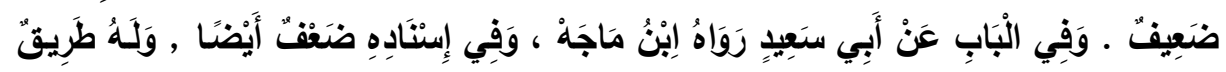

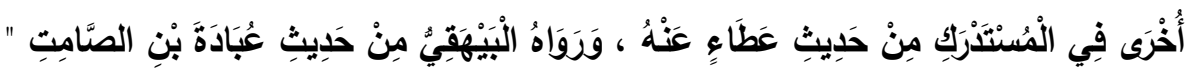

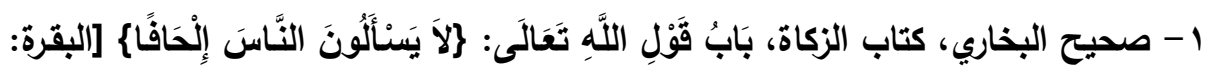

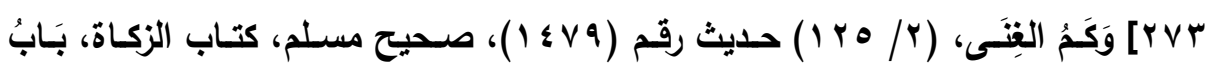

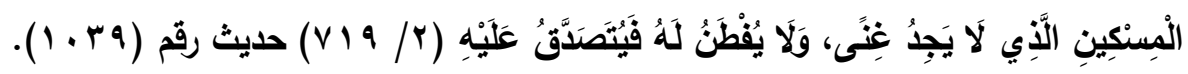

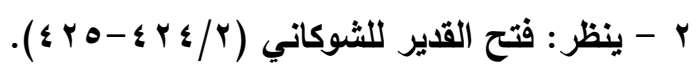




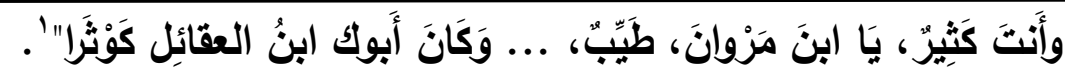

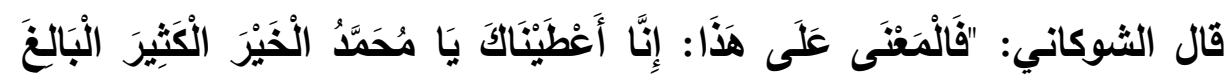

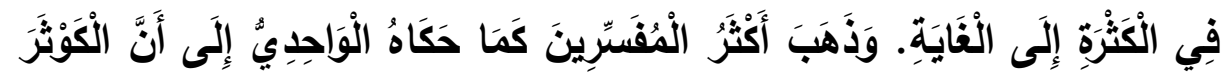

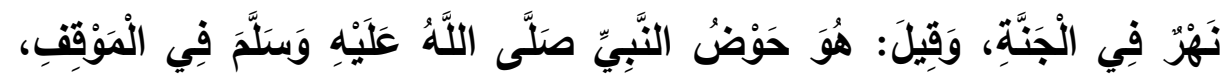

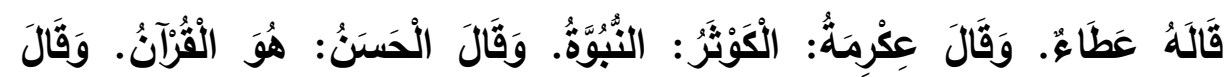

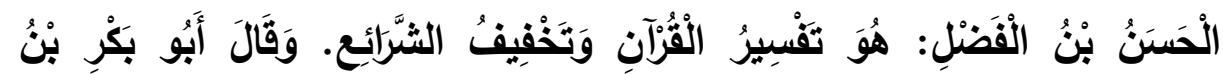

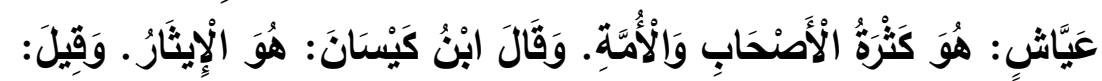

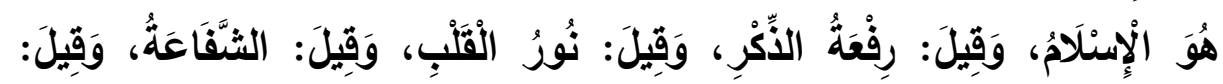

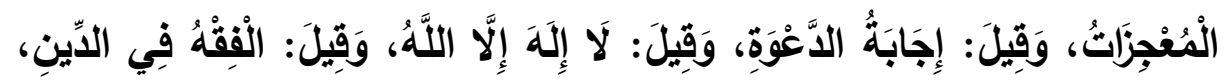

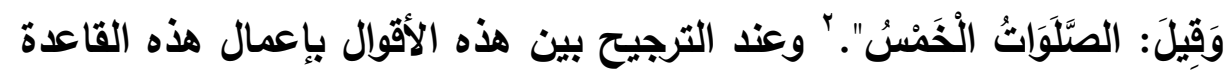

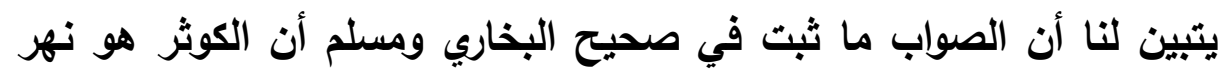

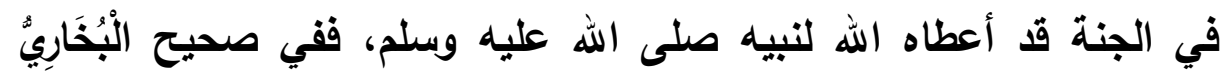

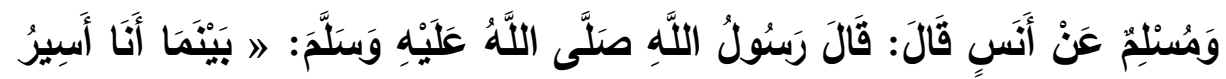

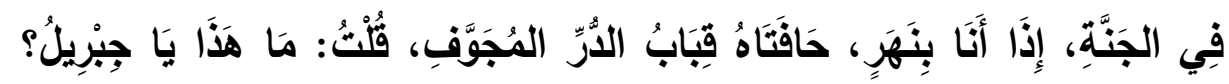

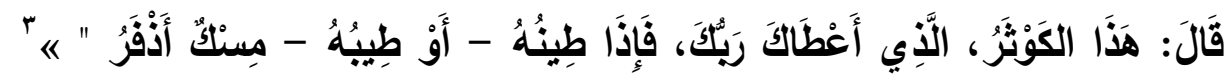

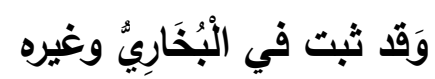

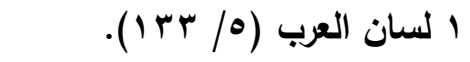

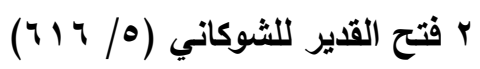

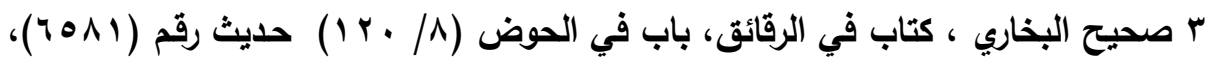

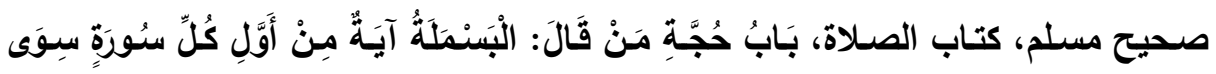

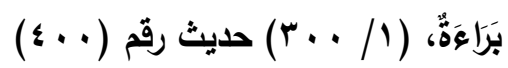




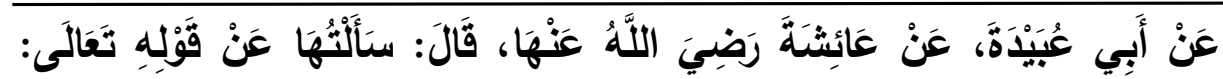

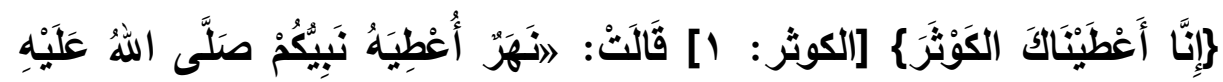

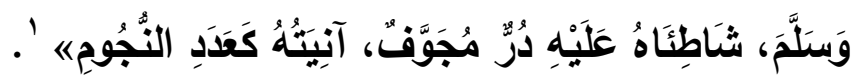

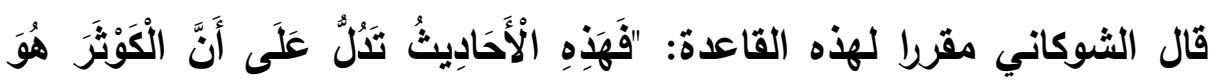

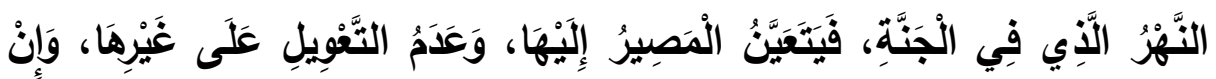

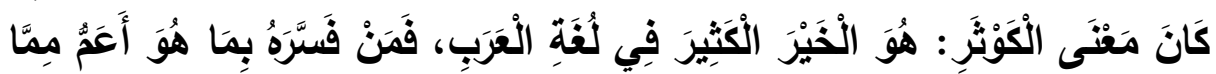

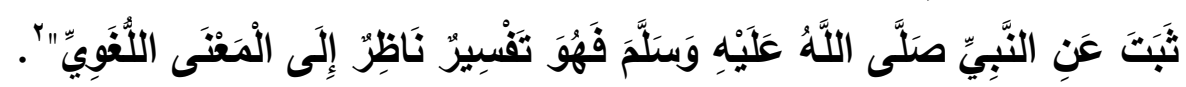
وأرى أن لا تعارض بين المعنى اللغوي والمعنى الثرعي، فهذا النهر من الخير

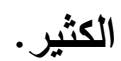

\section{الخاتمة: وفيها أهم النتائج والتوصيات:}

1-أن قواعد التفسير من أهم ما يعين الباحث على معرفة التفسير

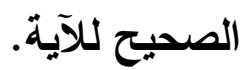

r-خير ما يفسر به القرآن بعد القرآن، هو حليث النبي صلى الله عليه

وسلم، ثم ما صح من أقوال الصحابة رضي الله عنهم أجمعين.

ب- بصار لهذه القاعدة إذا كان الحديث صحيحاً ومؤيداً لأحد الأقوال.

؛ - قواعد الترجيح موضوع جدير بالبحث، والتقصي لكتب التفسير كابن

كثير، وفتح القدير، وروح المعاني، والتحرير والتنوير، وغيرها،

يفرد كل واحد منها برسالة علمية، أو كل قاعدة.

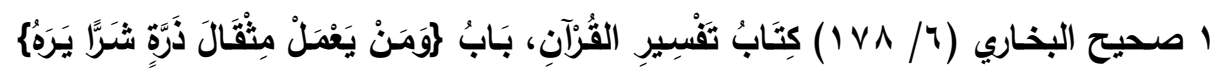

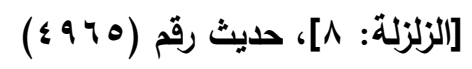

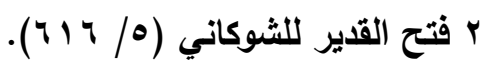




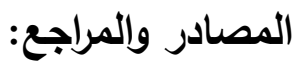

1.أحكام القرآن، للقاضي محمد بن عبد الله أبو بكر بن العربي المعافري

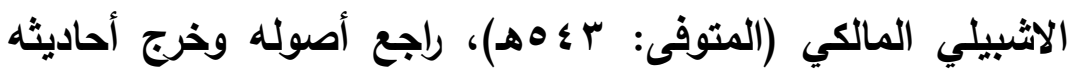
وعلَّق عليه: محمد عبد القادر عطا، الناشر: دار الكتب العلمية، الكائه

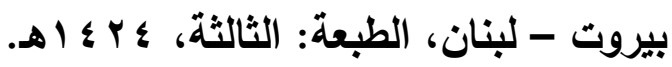
r. أسد الغابة في معرفة الصحابة، لأبي الحسن علي بن أبي الكرم محمد بن محمد بن عبد الكريم بن عبد الواحد الثيباني الجزري، عز الدين

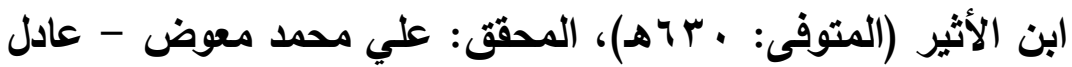

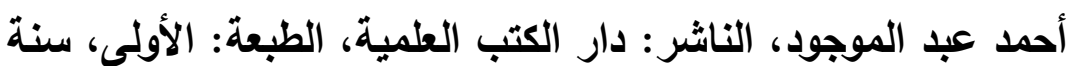

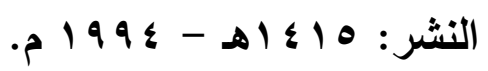

r.تاج العروس من جواهر القاموس، لمحمّل بن محمّد بن عبد الزنّلق

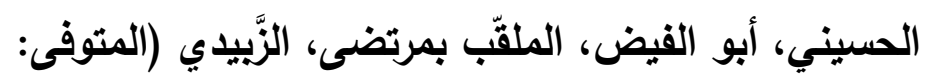
هـ ـ ا اهـ)، المحقق: مجموعة من المحققين، الناشر : دار الهاية.

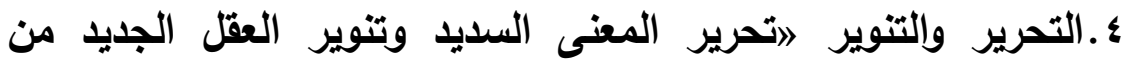
تفسير الكتاب المجيده، لمحمد الطاهر بن محمد بن محمد الطاهر بن عاشور التونسي (المتوفى: باهو أهـ)، الناشر: الدار التونسية

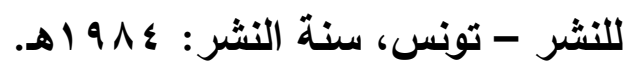
ه.تفسير القرآن العظيم، لأبي القداء إسماعيل بن عمر بن كثير القرئشي

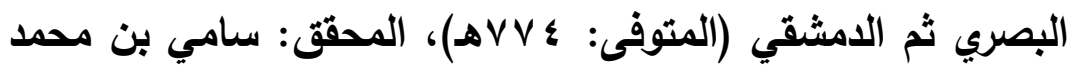

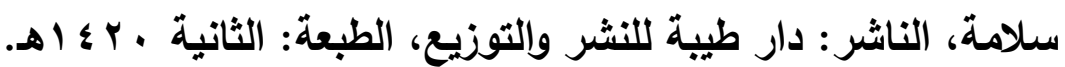
7.التوقيف على مهمات التعاريف، لزين الدين محمد المدعو بعبد الرؤوف بن تاج العارفين بن علي بن زين العابدين الدادي ثمث 


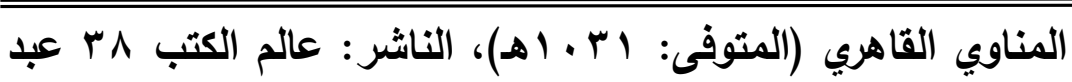

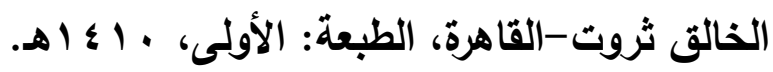

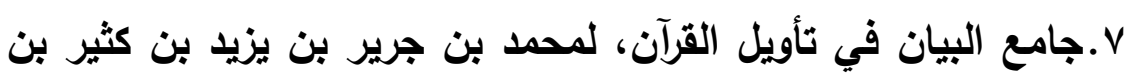

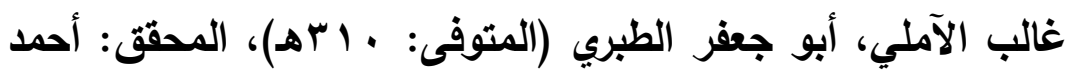

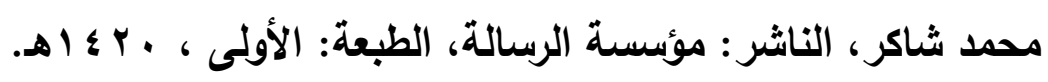

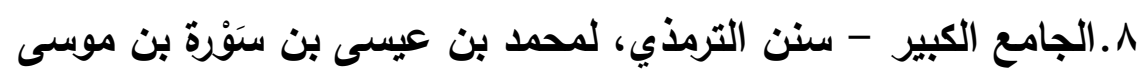

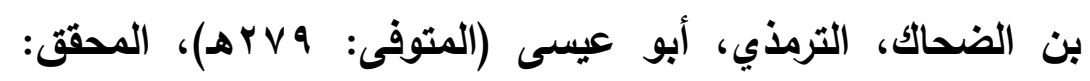
بثار عواد معروف، الناشر: دار الغرب الإسلاهي - بيروت، سنة الفنة

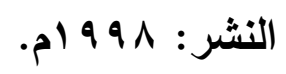

9.الجامع المسند الصحيح المختصر من أمور رسول الله صلى الله عليه

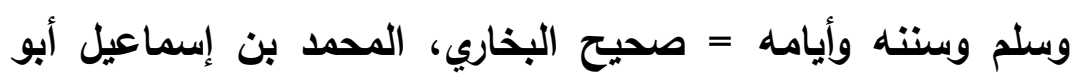

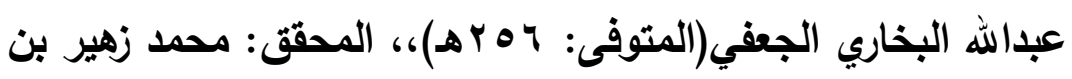

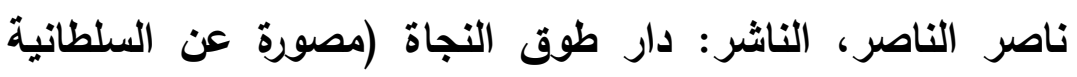

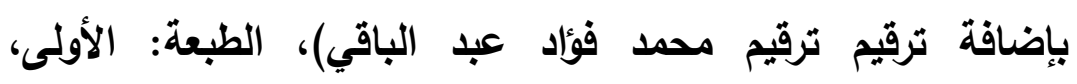
ه $1 \leqslant Y r$

• 1. روح المعاني في تفسير القرآن العظيم والسبع المثاني، لثهاب

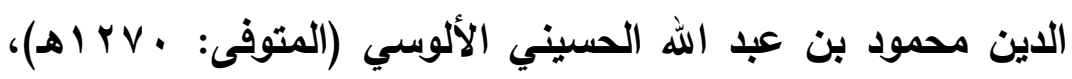

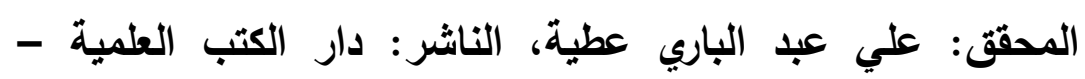

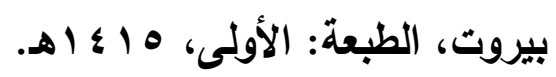

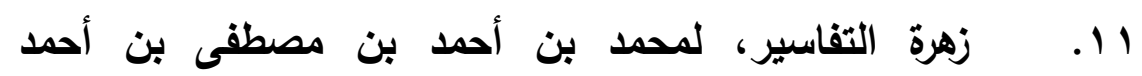

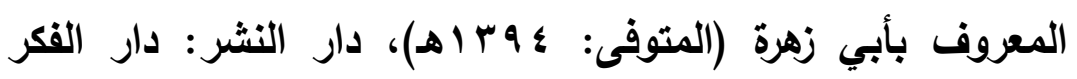

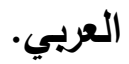




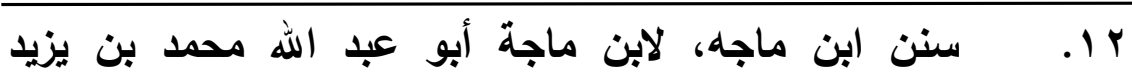

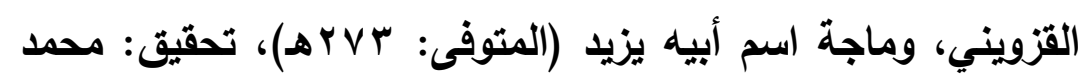

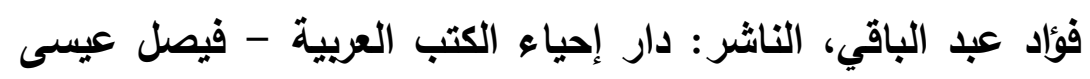
البابي الحلبي.

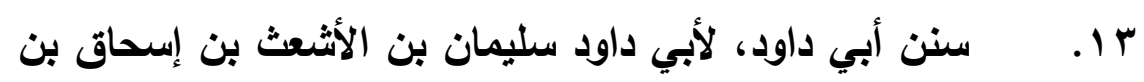

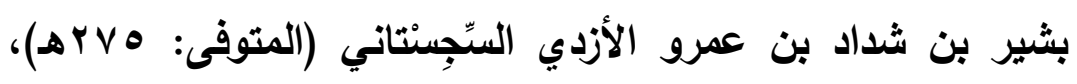
المحقق: محمد محيي الدين عبد الحميد، الناشر : المكتبة العصرية،

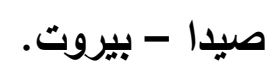

ـ ا. الصحاح تاج اللغة وصحاح العربية، لأبي نصر إسماعيل بن

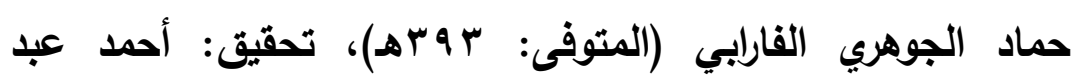

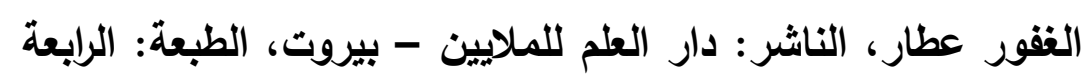

$$
\rightarrow 1 \varepsilon \cdot V
$$

10. فتح القدير، لمحمد بن علي بن محمد بن عبد الله الثوكاني

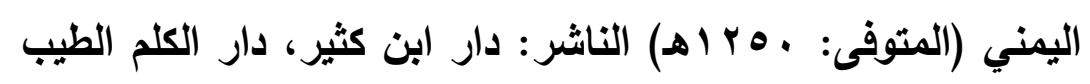

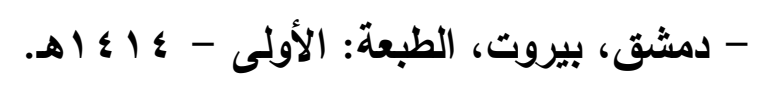

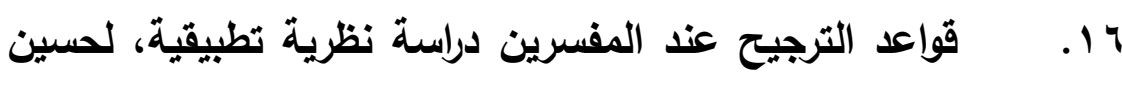

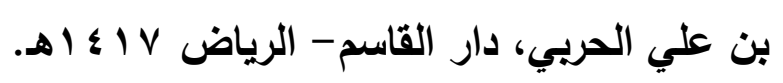

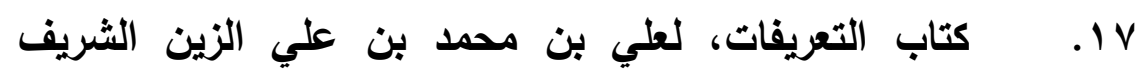

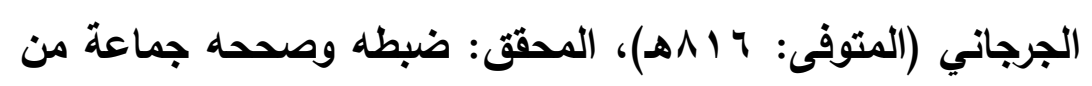

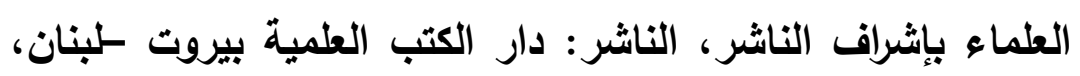

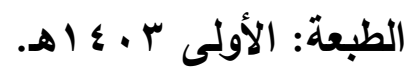


11. لسان العرب، لمحمد بن مكرم بن على، أبو الفضل، جمال

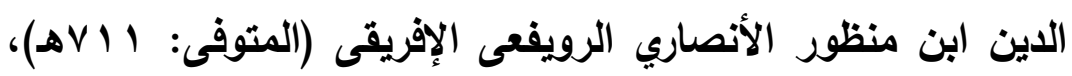

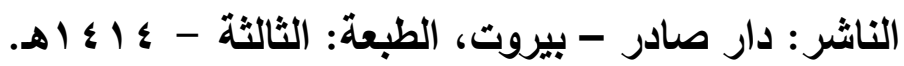
9 1. مجموع القتاوى لتقي الاين أبو العباس أحمد بن عبد الحليم

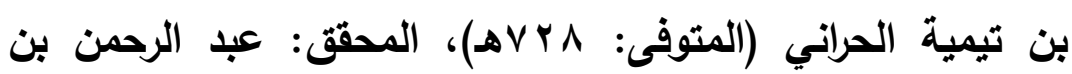

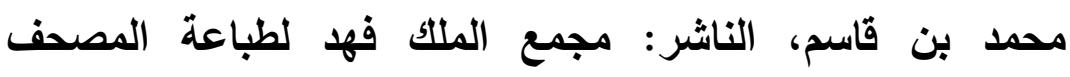
الشريف، المدينة النبوية، المملكة العربية السعودية، عام النشر: 4

• • . المحرر الوجيز في تفسير الكتاب العزيز، لأبي محمد عبد الحق بن غالب بن عبد الرحمن بن تمام بن عطية الأندلسي المحاربي (المتوفى: بـهـ)، المحقق: عبد السلام عبد الثافي محمد، الناشر: دار الكتب العلمية - بيروت، الطبعة: الأولى هـ

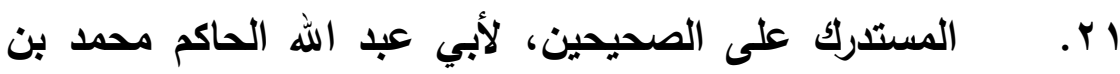
عبد الله بن محمد بن حمدويه بن نُعيم بن الحكم الضبي الطهماني النيسابوري المعروف بابن البيع (المتوفى: ه هـ هـ)، تحقيق:

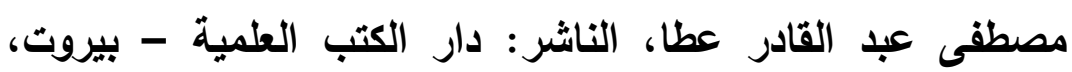

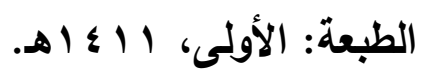

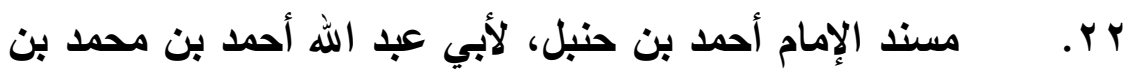
حنبل بن هلال بن أسد الثيباني (المتوفى: إ؟بهـ)، المحقق: شعيب الأرنؤوط - عادل مرشد، وآخرون، إشراف: د عبد الله بن عبد

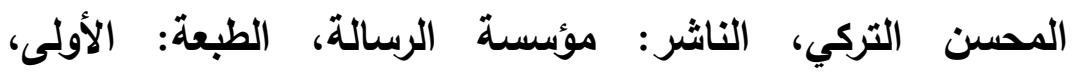




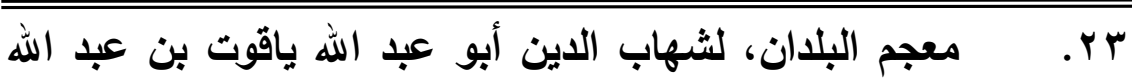

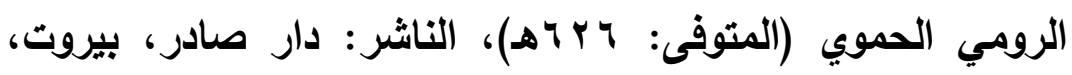
الطبعة: الثانية، 999 19 م.

צ r. معجم مقاييس اللغة، لأحمد بن فارس بن زكرياء القزويني الرازي، أبو الحسين (المتوفى: هوبهـ)، المحقق: عبد السلام محمد

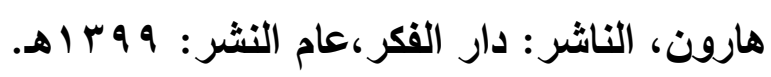

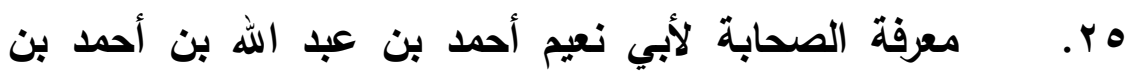

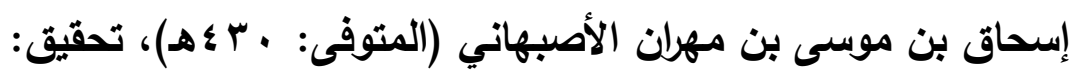

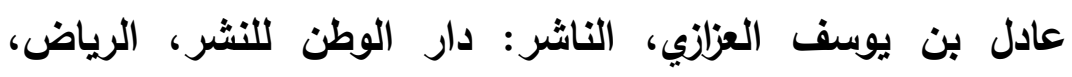

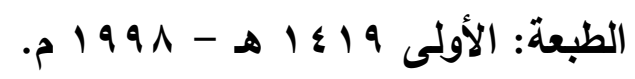

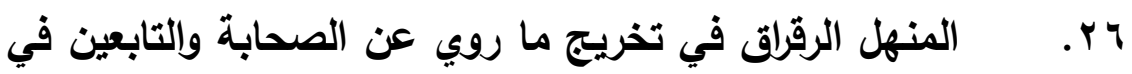
تفسير \} يوم يكثف عن ساق\{ وإبطال دعوى اختلافهم فيها تأليف

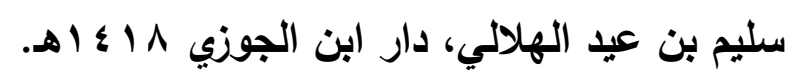

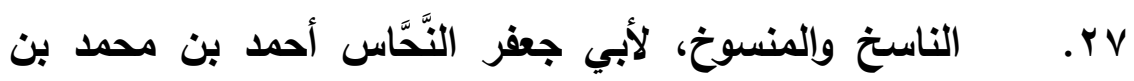

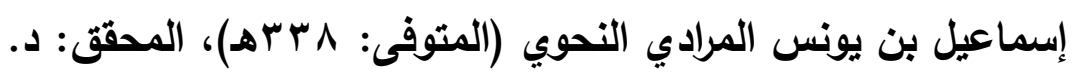
محمد عبد السلام محمد، الناشر: مكتبة الفلاح - الكويت، الطبعة:

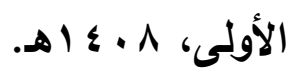

